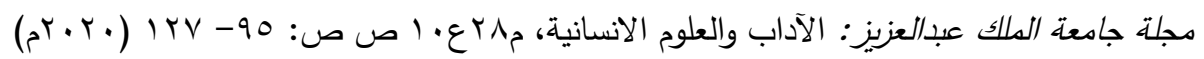
DOI:10.4197/Art.28-10.5

\title{
(رواية أبان بن تغلب في سور الفاتحة والبقرة وآل عمران وأثرها في التفسير)
}

\section{د. محمد بن أحمد بن محمد بن معيض}

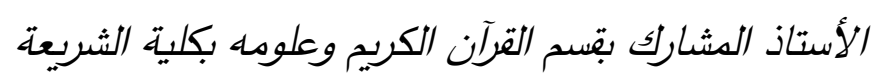

$$
\text { وأصول الدين - جامعة الملك خالد }
$$

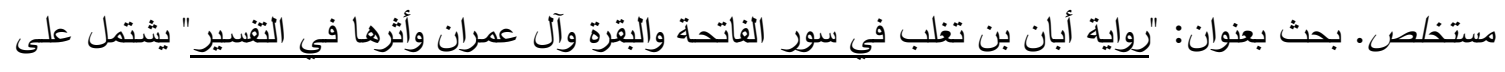

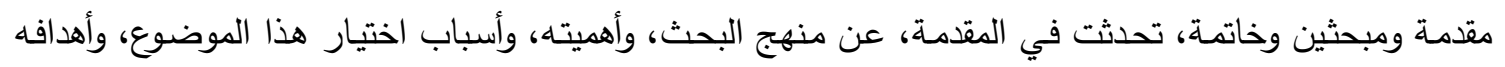

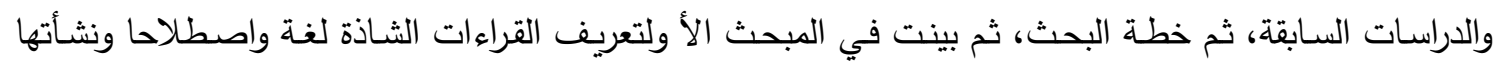

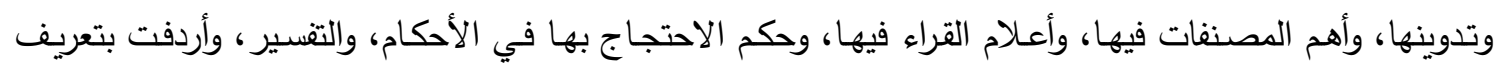

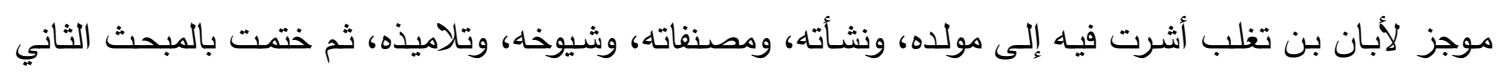

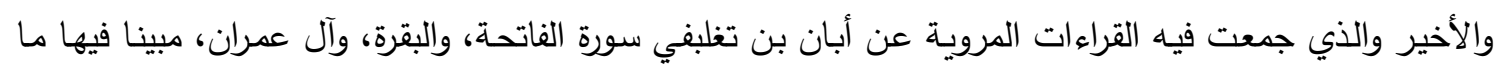

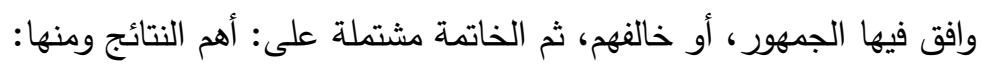
1- أن رواية أبان بن تغلب من القراءات الثاذة.

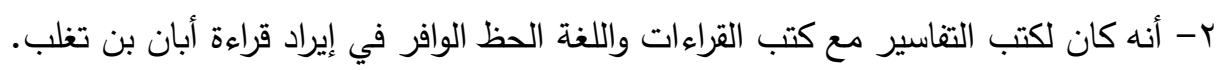
r- أحصيت تسعة عشر موضعاً، من خلال سورة الفاتحة، والبقرة، وآل عمران. وأما التوصيات فكانت مايلي:

1 - حث الباحثين وتحفيزهم، على البحث الجاد والعمل الدؤوب في جمع قراءة أعلام القراءات الثاذة، وبيان أثرها في التقسير • r- العمل على جمع قراءة أبان بن تغلب في مصدر واحد حتى يمكن الإفادة منها. الكلمات المفتاحية: رواية - أبان - بن تغلب - قراءات - القرآن الكريم.

وصحبه وسلم، وبعد:

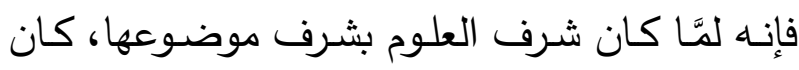
علم القرآن وقراءاته بصفة خاصة وعلوم القرآن بصفة

\section{المقدمة}

الحمـــــلله رب العـالمين، والصــلاة والســلام علـى المبعـوث رحمـة للعـالمين سـيدنا محمــ وعلى آلـه ولهـ 
وأثر ذلك على التفسير مـع توجيه القراءات التي قد

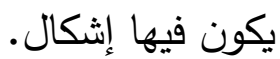

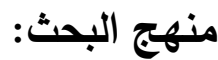

كان منهج الباحث دراسة استقرائية استقصائية لرواية

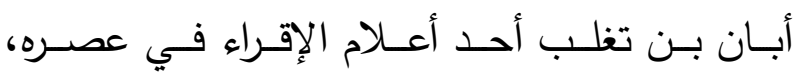
اقتصـرت فيـه علـى القـراءات الفرشـية، ولـــ أذكـر أصول أبان بن تغلب لكثرة مسائله حيث يحتاج إلى بحث مستقل، وقد اعتمدت في ذكر تلك القراءات على الكتب التي تخصصت في إيراد قراءته، وهي (إتحاف فضـلاء البشر ) للبنـا الدمياطي، و (المبهج)

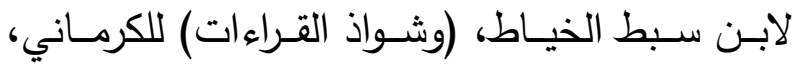
(والبحر المحيط) لأبسي حيـان، (والمحرر الـوجيز)

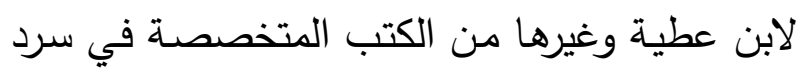

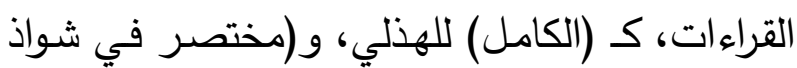
القرآن) لابن خالويه، و(النشر) لابن الجزري.

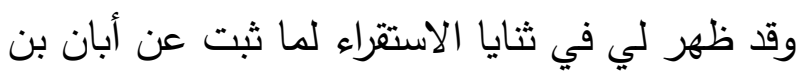

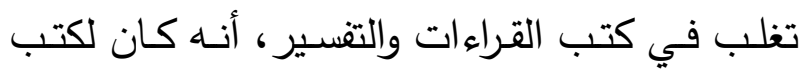
التفاسير الحظظٌ الـوافر في سـردها والوقوف عليهـا وإيرادها، خاصـة تفسير (المحرر الوجيز في تفسير الكتاب العزيز) لابن عطية الأندلسي وتفسير (البحر

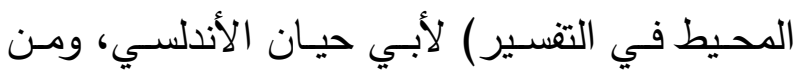

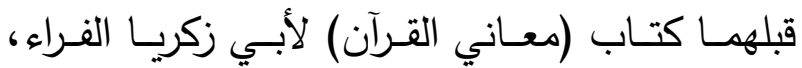
وأيضًا (معاني القرآن وإعرابه) للزجاج. والجدير بالذكر أن هذه التفاسير انفردت بكثير مها ثبت عن أبان بن تغلب، عما هو موجود في كتابي

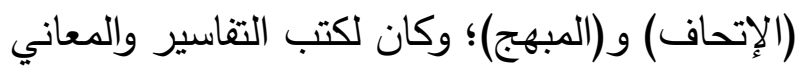

عامة من أشرف العلوم وأعلاها قدرًا، وأسماها منزلةً؛

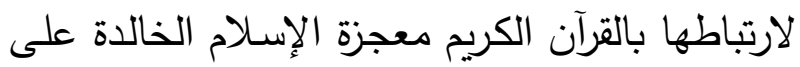
مـر العصـور واختـلاف الـدهور ولا شـك أن أهميـة

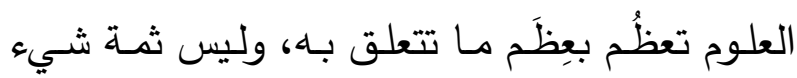

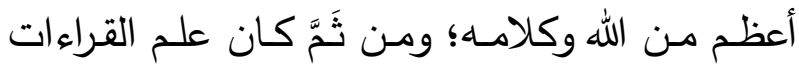
وعلوم القرآن من أرفع العلوم مكانتة، وأكثرهـا أهميـةً وفي هذا الصـد يقولُ ابن عطيـة - رحمـه الله "فعلم أن شرف العلم على قدر شرف المعلوم ووجد أن علم كتاب الله هو أمستن العلوم حبـالا وأرسخها جبالا وأجملها آثارا وأسطعها أنوارا وأيقن أنـه أعظم الته العلوم تقربـاً إلى الله تعالى وتخليصـاً للنيات، ونهياً عن الباطل وحضاً على الصالحات"( (1). وعلـم القـراءات مـن العلـوم التي لا يسـتغني عنهـا المفسر لكتاب الله تعالى؛ لأنه به تُعرف كيفية النطق بـالقرآن، وبـهـ يترجح بعض الوجـوه المحتملــة على لـى

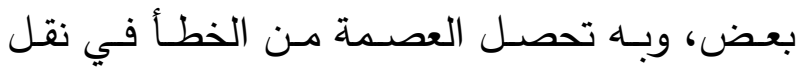
القرآن، ومعرفة ما يقرأ به كل إمام من أئعة القراءة،

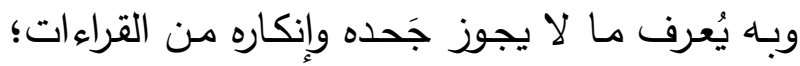

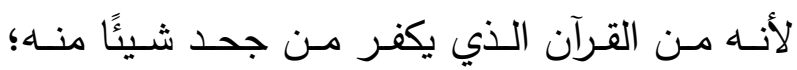

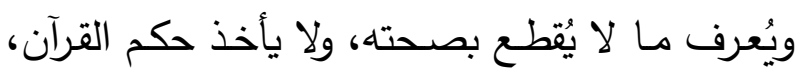

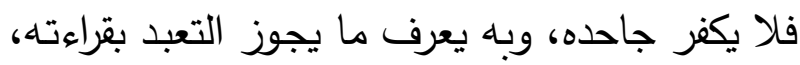
وما لا يجوز ... إلخ (ن).

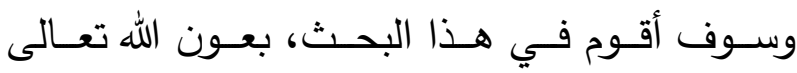

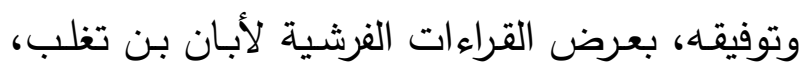

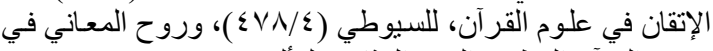
تفسير القرّآن العظيم والسبع الثثاني، للألوسي (1/7). 
أعلامها المتقنين.

$$
\text { أهداف البحث: }
$$

يسعى هذا البحث لتحقيق الأهداف الآتية:

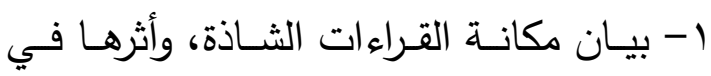
إظهار المعنى أو بيان الأحكام. r- كثف اللثام عن صحيحها فيقبل، والثـاذ

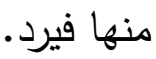
ب- العهـل على إثراء المعـاني التقسـيرية مـن خـلال عرضـها، ودراستها، وبيـان آثارها في المعـاني

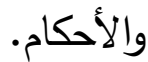

الداسات السابقة في قراءة أبان بن تغلب: أما الدراسات السابقة في رواية أبان بن تغلب منفرداً

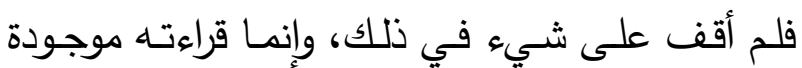
منشورة ضمن كتب معينة صُنِّفت في عموم القراءات

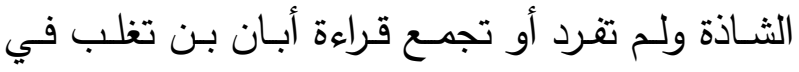

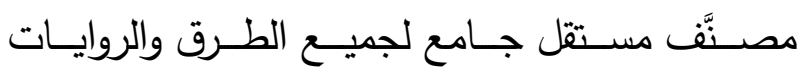
المختلفة، من كتب القراءات والتقسير واللغة، وتوجيـه المشكل منها.

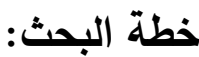

يتكون هذا البحث مـن مقدمـة، ومبحثين، وخاتمـة،

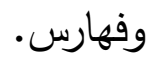
المقدمـة: فتحدثت فيها عـن تعريف علم القراءات

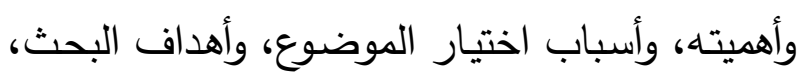
والدراسات السابقة فيه، وخطة البحث.

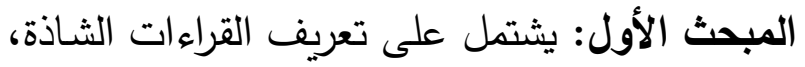
وعلى حكم الاحتجاج بها وترجمة لأبان بن تغلب من لنس
الفضل الأكبر في إثبات قراءته، سواء كانت قراءة موافقة لما تواتر عليه، أم قراءة شاذة. أهمية البحث:

من المعلوم أن علم القراءات، من أحد مفردات علوم

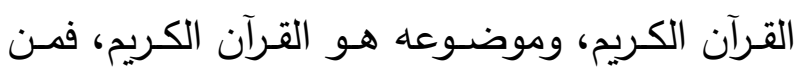

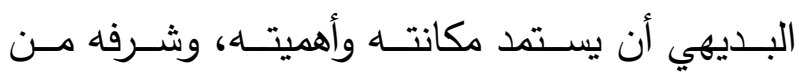

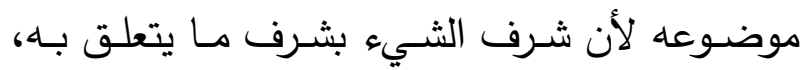

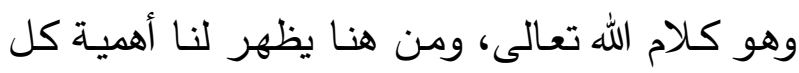
موضوع يتعلق بكتاب الله - عز وجل -، سواء أكان

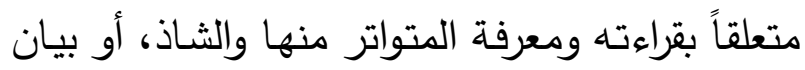

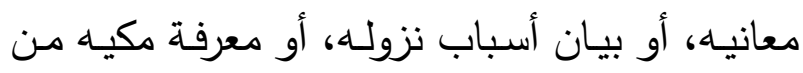

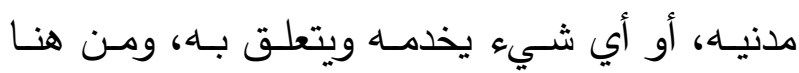
يظهر لنا أهمية هذا البحث.

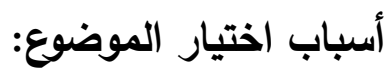

والسبب في اختياري لهذا الموضوع الأمور الآتية: ا- الحرص على إبراز كل مـا هو جديد في الهي

هذا العلم الجليل، وحرصي على دراستها ومطالعتها لما اشتملت عليه من معان رائعة.

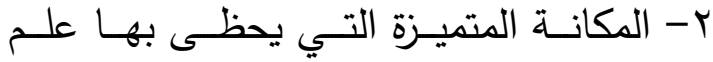

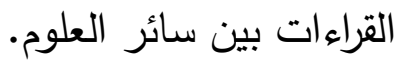

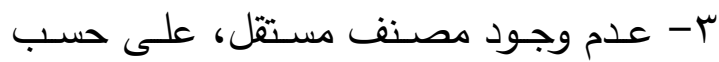

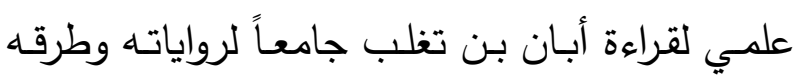
المختلفة من كتب القراءات والتنسير واللغة. ع - إظهار مكانة أبان بن تغلب في القراءات

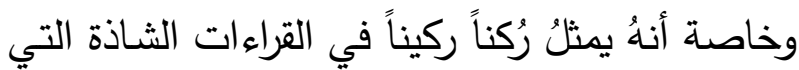
حملت معـان جديدة لكثير مـن الآيـات، فهو مـن 
أولاً: تعريف القراءات الثاذة لغة واصطلاحاً:

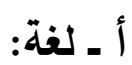

القراءات: جمع مفرده قراءة، وأصل مادتها تعود إلى لع

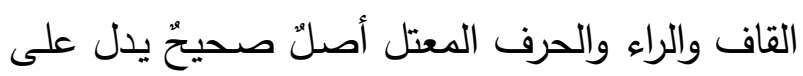

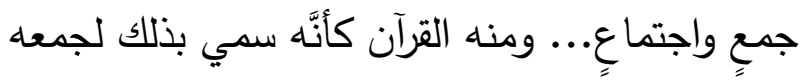
ما فيه من الأحكام والقصص وغير ذلك.

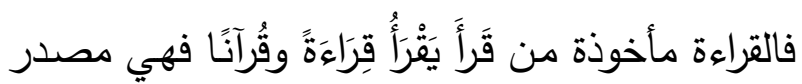

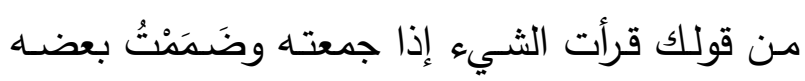
إلسى بعـض(')، وفي اللسـان: "قـرأتُ الثــيء قرآنـاً

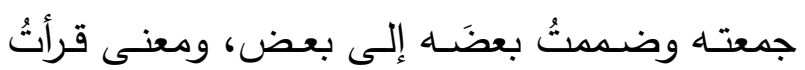
القرآن لفظتُ باه مجموعاً أي: ألقيته" (؟).

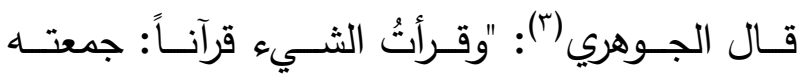
وضمدتُ بعضـه إلى بعضٍ، ومنسه قولهم: مـا قرأتُ

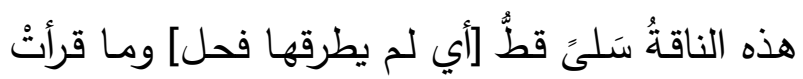
جنيناً، أي لم تضم رحمها على ولادٍ.

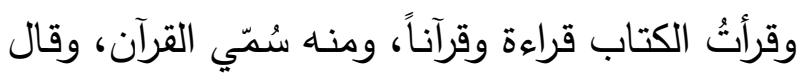

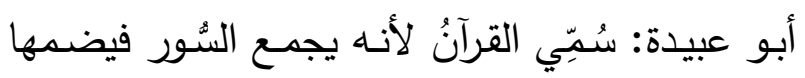

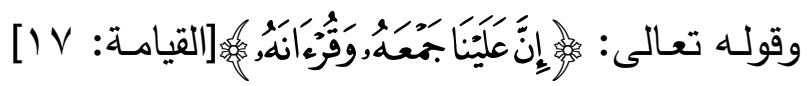
أي: جمعـه وقراءته. قـال ابن عباس: فإذا بينَّاه لك بالقراءة فاعمل بما بيَّنَّاه لك" (๕).

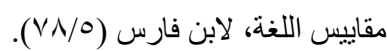

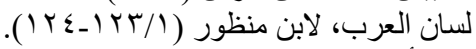

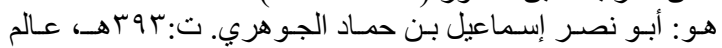

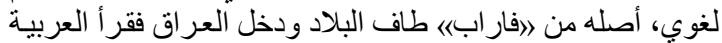

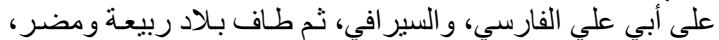

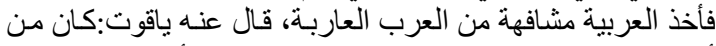

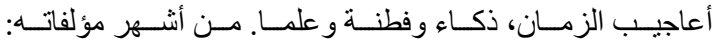

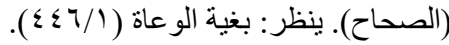
الصحاح تاج اللغة وصحاح العربية، للجوهري (10/(10). ).
حيث مولده ونشـأته وصفاته، وشيوخه، وفيـه ثلاثة مطالب:

المطلـبـ الأول: القـراءات الثــاذة مـن حيـث: التعريـف، والنشـأة، والتدوين وأهم المصنفات فيهـا، وأعلام القراء فيها:

أولاً: تعريف القراءات الثاذة لغةًة واصطلاحاً. ثانياً: نشأة القراءات الثاذة. ثالثاً: تدوين القراءات الثـاذة وأهم المصنفاء فيها. رابعاً: أعلام القراء فيها. المطلـب الثـاني: حكـم الاحتجــاج بـالقراءات

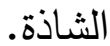

المطلب الثالث: تعريف موجز بالإمام أبان بن

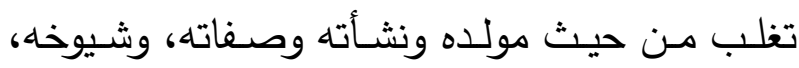

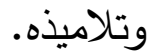
المبحـث الثـاني: فأتحـدث فيـهـ عـن القـراءات الفرشية المرويـة عن أبـان بن تغلب مـا وافق القراء

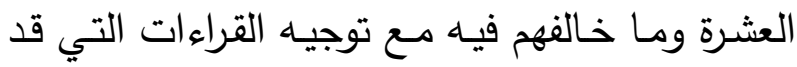
يكون فيها إثكالاً، وأثرها في التفسير ، إن وجد.

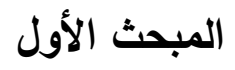

يثـتمل على تعريـف القراءات الثــاذة، وعلى حكم

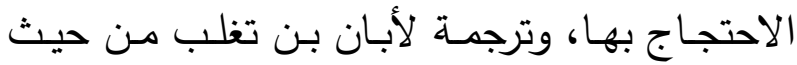
مولده ونشأته وصفاته، وشيوخه، وفيه ثلاثة مطالب:

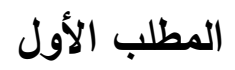

القراءات الثاذة من حيث التعريف، وإلنشأة، والتدوين، وأهم المصنفات فيها، وأعلام القُراء فيها 
على القاعدة والأصــول فكـل شـئ منفـردٌ فهـو شـاذ والثَّـاذ في الاصــلاح يختلف مفهومسه حسـب كل علم، فهو عند النحـاة غير مـا عند علمـاء السـنة، ويختلف عنهما لدى علماء القراءات. فالقراءات الثـاذة إذاً هي التي تقابل القراءات المتواترة. وفي الاصـطلاح هـي: مـا فقدت ركنًا أو أكثر مـن أركان القراءة المقبولة وهي:

1- التواتر على رأي الجمهور ، وصـحة السـند مع الاشتهار على رأي ابن الجزري. r- موافقة وجه من وجوه اللغة العربية. r- موافقة رسم المصاحف العثانية. إذاً القراءة الشاذة هي كل قراءة بقيت وراء دقياس ابن الجزري الذي قـال: "...ومتى اختل ركن مسن هذه الأركـان الثلاثـة أطلـق عليهـا ضـعيفة أو شـاذة أو باطلـة سـواء كانـت عـن السبعة أم عمـن هـو أكبر منهم" (v) (v)

\section{وقال في طيبة النشر (^):}

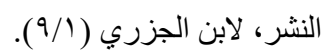

طيية النشر، لابن الجزري (صَ) (ه).
ب ـ القراءات اصطلاحاً: عرَّفها الإمـام ابـن الجزريي(') القراءات بأنهـا: "علم بكيفية أداء كلمات القرآن واختلافها، مَعْزُوٌٌ لناقله"(r).

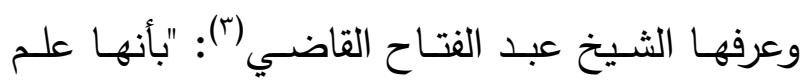

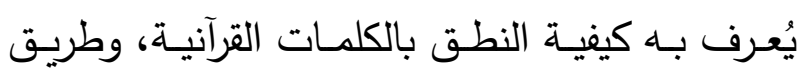
أدائها اتفاقًا واختلافًا مع عزو كل وجه لناقله"(؛). - والثـاذ: يطلق ويراد بـه الندرة، والانفراد، والتفرق، والخروج عن القاعدة، وهو ما سنوضحه فيما يأتي:

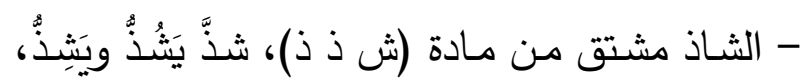

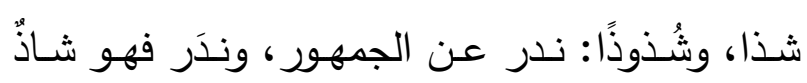

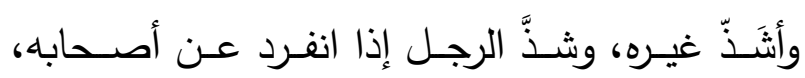
وكذلك كل شيء منفرد فهو شاذٌ، وكلمـة شاذة، وشذَّا عن الجماعة: انغرد عنهم شذوذاَ(ْ).

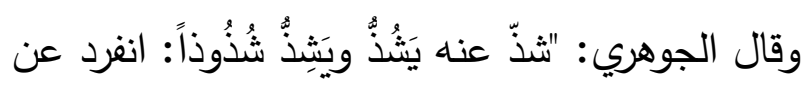

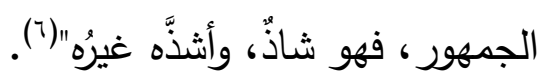
فالثذوذ يدل على الانفراد والندرة، والتفرق والخروج هو: أبو الخير محمد بن محمد بن محمد الجزري الثـافعي ولا

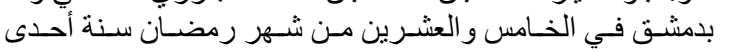

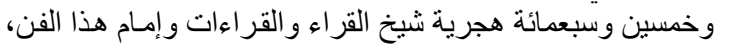

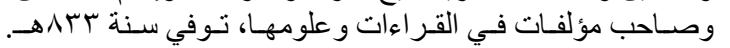

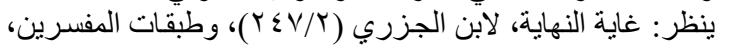
لاللاوودي (r/ آج).

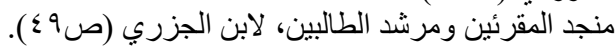

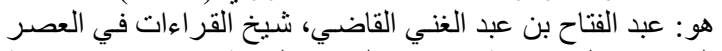

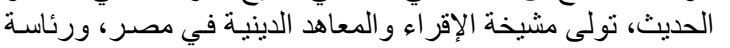

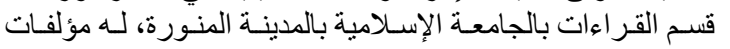

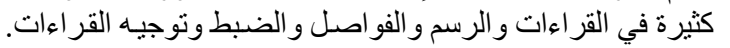

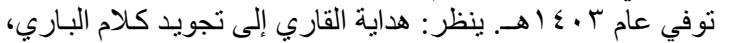

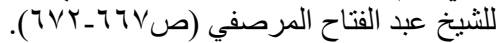
البدور الز اهرة في القراءات العشر المتواترة، لعبد العبد الفتاح القاضي،

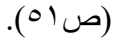

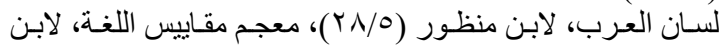

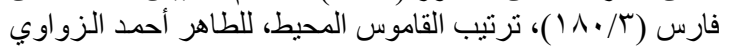
. ( (

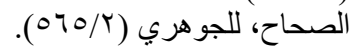




\section{فكلمـا وافق وجـهـ نحـو * وكان للرسم احتمالاً يحوي \\ وصـح إسـنادا هو القرآن * * فهـــه الثلاثـــة الأركــــان \\ وحيثما يختل ركن فاثبت * * شـذوذه ولـو فـي السـبعة}

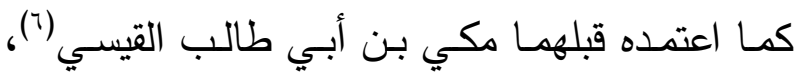

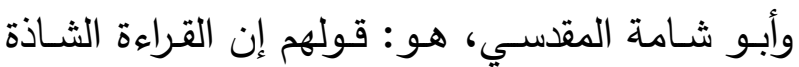
هي: "القراءة التي صـحَّ سندها ووافقت اللغة العربية ولو بوجه وخالفت المصحف" (')

لذا قال أبو شامة في بيان أركان القراءات: "كل قراءة

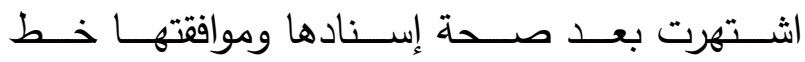
المصحف، ولم تتكر من جهة العربية، فهي القراءة المعتمدة عليها، وما عدا ذلك فهو داخل في حيّز

الثاذ والضعيف، وبعض ذلك أقوى من بعض" (^).

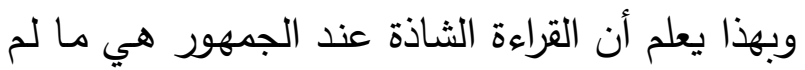
تثبت بطريق التواتر •

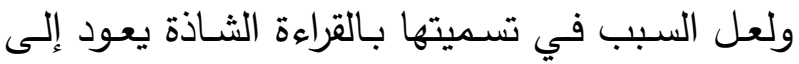
أنها شذت عن الطريق الذي نقل به القرآن حيث نقل بـاءل بجميع حروفه نقلاً متواترًا.

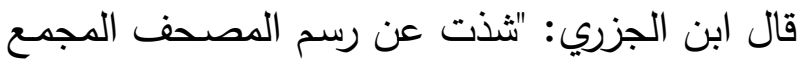
عليه وإن كان إسنادها صحيحًا" (9.

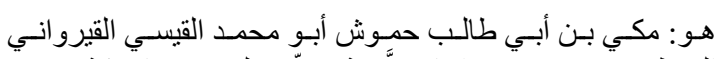

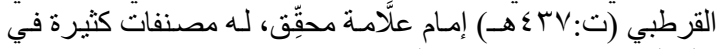

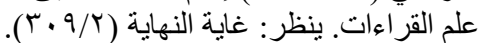

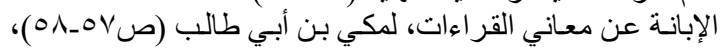

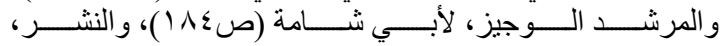

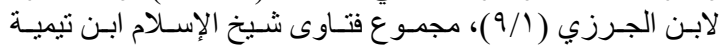
( )

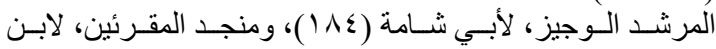

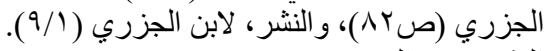

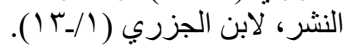

فالقراءة الثـاذة هي: التي لم يصـح سندها وخالفت الرسم ولا وجه لها في العربية. أو هي: "القراءة التي فقدت ركناً من أركان القراءة التهاءه

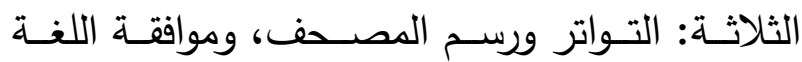

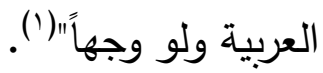
وعُرفت أيضـا: "بأنها كل قراءة وافقت العربيـة ولو بوجها ووافقت أحد المصاحف العثمانية ولو احتمالاً

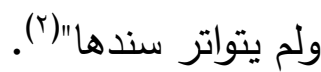

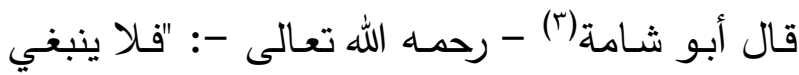
أن يغتر بكل قراءة تُعزى إلى واحد من هؤلاء الأئمسة

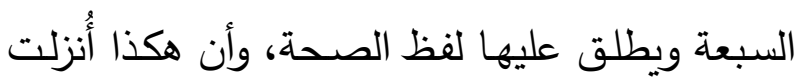

إلا إذا دخلت في ذلك الضابط" (؟).

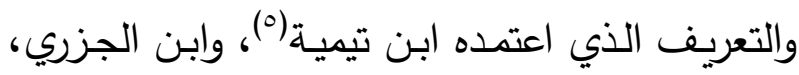
ذكر ها ابن الجزري لابن الجزي (النشر (9/9)، غيث النفع، للصفاقسي (ص/9-1).

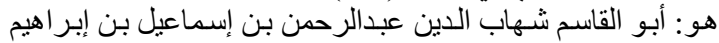

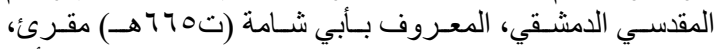

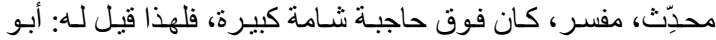

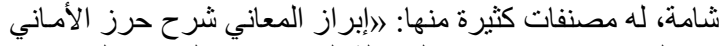

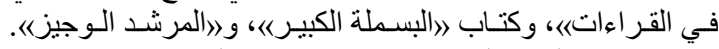

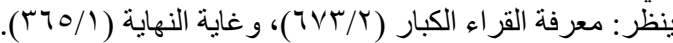

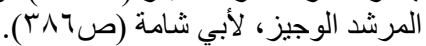

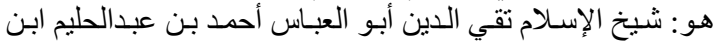

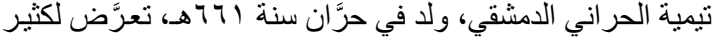

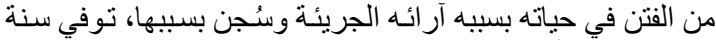

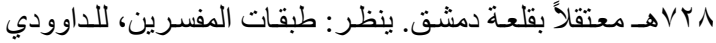

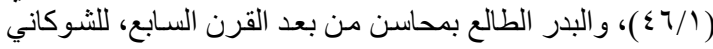




$$
\text { جبريل - عليه السلام -"(r). }
$$

ولمـا شـذت قـراءات بعض الصـحابة عـن الإجمـاع وعـن التـواتر حكم عليهـا أنهـا ليســ مـن الأحـرف السبعة، ولذلك كان علماء الأمة يحذرون حذراً شديداً في قبول مثل هذه القراءة وأمثالها، ولا يعدونها قراءة صـحيحة، وإنمـا كـان يستثـهدون بهـا في ترجيح الأحكام، وتوجه اللغة وغير ذلك، ولا يأخذونها على

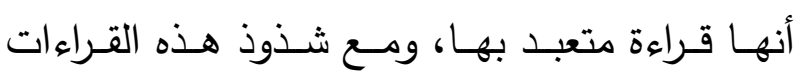
وخروجهـا عـن الإجمـاع في الوقـت المبكـر إلا أن القراءة بها لم تتوقف عند عدد من القراء بل تمسكوا

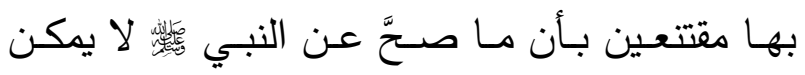
تجاهلـه، كمـا أثـار إلى ذلك مكي القيسـي بقولـه: "ولذلك تمـادى بعض الناس على القراءة بما يخالف خط المصحف ممـا ثبت نقله، وليس ذلك بجيد ولا بصواب لأن فيـه مخالفـة الجماعة" (ז)، وهكذا استمر الوضــع ثلاثـة قرون متتاليـة إلى أن جـاءت عوامـل قويـة أدت بها إلى الفصل التام عن المتواتر وتحديد معالمهـا وإطـلاق الشـذوذ عليهـا فقد كره كثيـر مـن علماء المسلمين حَمَلَتها وأطلقوا عليهم عبارات مُنفرة كقول ابن أبي عبلة(๕) "من حمل شاذ العلم حمل شرًا كبيرًا"، وتعرض بعضهم للضرب من قبل ولاة الأمر

منجد المقرئين، لابن الجزري (صسوه)، وكتاب المصساحف، لابن

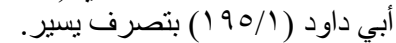

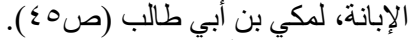

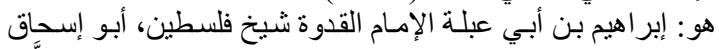

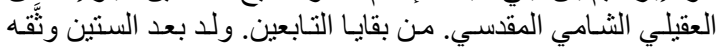

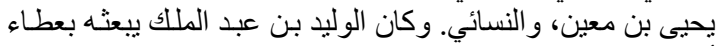

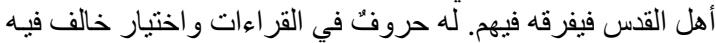

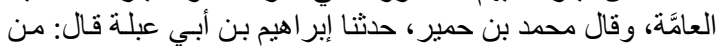

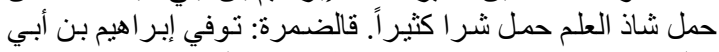
عبلة سنة اثتتين وخمسين ومائة. ينظر : غاية النهاية (19/1 (1) ).
وكانت تسـى بالقراءة الزائدة وأول مـن سماها بهذا

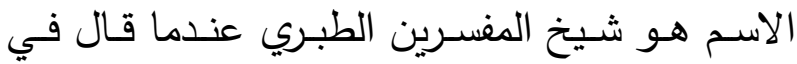

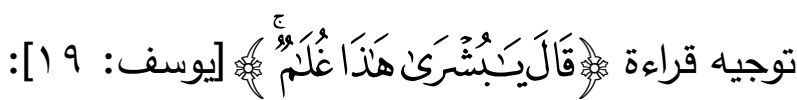

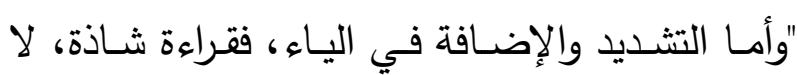

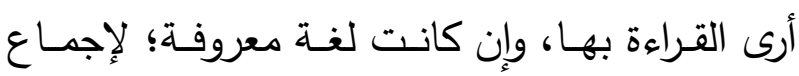
الحجة من القراءة على خلافها" ('). ثانياً: نشأة القراءات الثاذة وأول ظهورها: لما جمع الخليفة عثمان بن عفان - رضي الله عنه -، الناس على مصحف واحد وهو مصحف الإمام

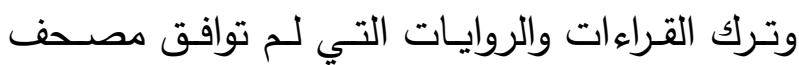
الإمـام كـان ذلكك بدايـة تحديد الصـحيح مـن الثـاذ

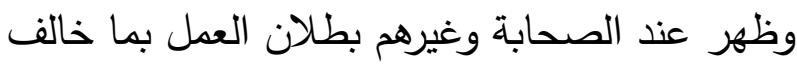
مصحف الإمام، وأرسل الخليفة عثمان - رضي وغي الله عنه - إلى كل مصر من الأمصـار المشهورة قارئًا تتفق قراءته والنسخة التي أرسلت إليه، حتى أصبح الصنح

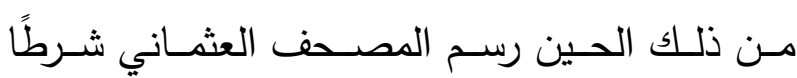

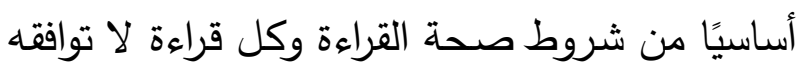
اعتبرت من الثاذ، وبقى خارج حدود الرسم عدد من

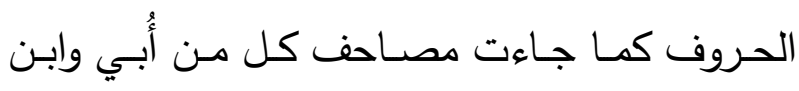
مسعود وغيرهما، وقد ذكر المتتبعون لشأن القراءات

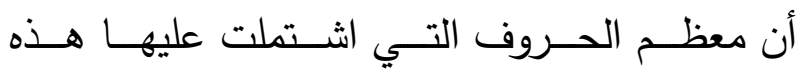
المصـاحف لم تثـهـ العرضـة الأخيرة التي عرضـها الرسول أصحاب هذه المصاحف تمسكوا ببعض القراءات ولم

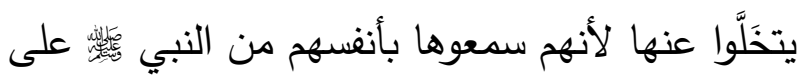


الأحرف السبعة التي نزل بها القرآن الكريم وبالتالي مصدرها هو الوحي، وبالتالي القراءات سُنَّة متبعـة

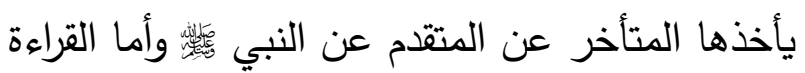
الشـاذة فلم يقل أحدٌ بأنها مـن الأحرف السبعة فيمـا وقفت عليه من المصسادر الأصيلة في ذلك، كما لم ينف أحدُ وجود شيء فيها من ذلك بـل كان هنـاك

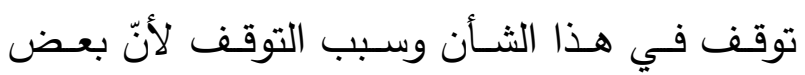

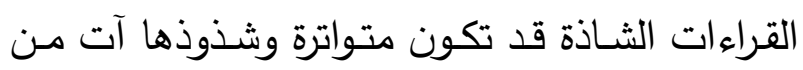
جهة غير السند، كما سيتضـح من خـلال بحثنا هذا في قراءة أبـان بن تغلب لكن لا يمكن القطع بأن

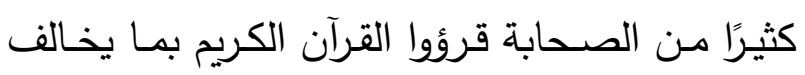
رسم المصـحف الذي جمع عليـه الخليفـة عثمـان - رلئ رضي الله عنه - الناسَ وأمرهم به وذلك لأن الغرض

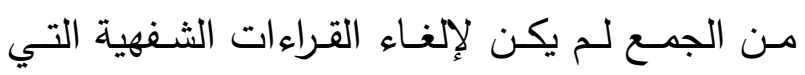
تلقوها من النبي

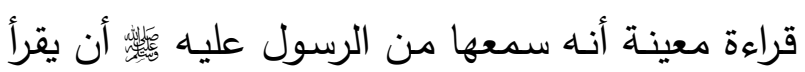
بها كما سمعها. ولذا يمكن القول بأن من القراءات التي أصطُلح على بهى

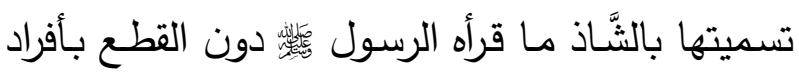
ذلك وأعيانـه لعدم إجمـاع الصـحابة عليـه كمـا ذهب إلـى ذلك ابـن دقيق العيد بقولـه: "الثـواذ نُقلت نَقْلَ

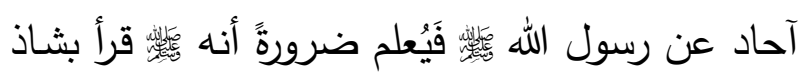
منها، وإن لم يُعَيَّن، كما أنَّ حاتماً نُقلت عنـه أخبـار في الجود، كلها آحاد، ولكن حصـل من مجموعها الحكـم بسـخائه وإن لـم يتعـيَّن مـا يَسْخى وإذا كـان
كمـا حصـل لابـن شَنَّبوذذ(')، واسـتتابته على قراءتهـ

وإقرائه بالشاذ(r) (؟) ذكـر أبـو حـاتم السجسـتاني (َ): "أنَّ أول مـن تتبـع بالبصرة وجوه القراءات وألَّفها وتتبَّع الشاذَّ منها فبحث عن إسناده: هارون بن موسى الأعور (£) وكان من القراء فكرَه الناسُ ذلك، وقالوا: قد أساء حين ألَّفها"(ه). وكـان أول مـن أطلـق عليهـا مصسطلح الثـذوذ هـو الإمام ابن جرير الطبري في تفسيره في مطلع القرن الرابع كما أسلفنا عندما تعرض لقراءة ابن مسعود في

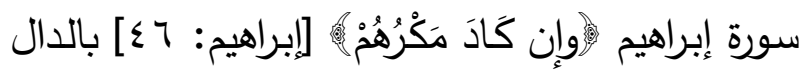

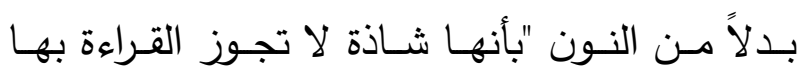

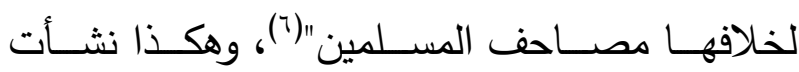
القراءات الشـاذة وانحسـرت دائرتها مـع مـرور الزمن وتحددت معالمها فأصبحت عِلماً من العلوم الّتي لها مهات أهميتهــا وأثرهــا الواضـــح فـي إثـراء اللغـــة العربيــة والأحكـام الشـرعية، وكذلك إثراء المعـاني في علم التفسيرير، وأمـا القـراءات القرآنيـة المتـواترة فهـي مـن

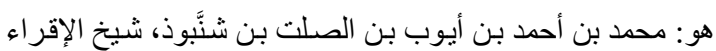

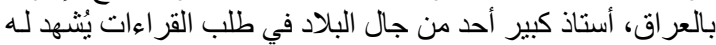

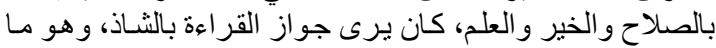

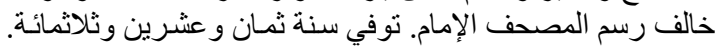

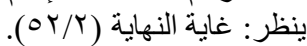

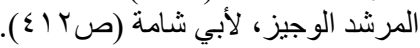

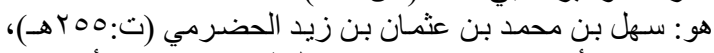

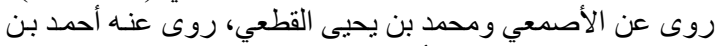

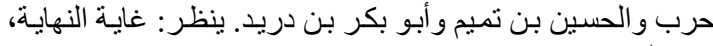

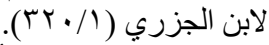

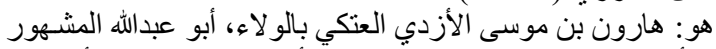

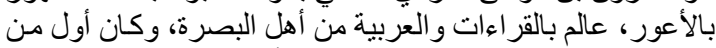

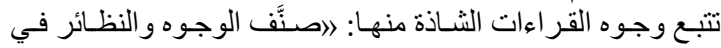

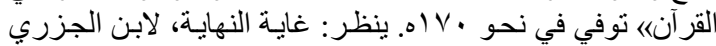
. $(\Gamma \leqslant \Lambda / T)$

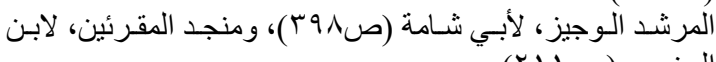

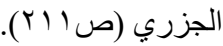

جامع البيان في تفسير القرآن، لابن جرير الطبري (1 (1 آ I ). 
ولا إثباتًا ولا حذفًا، ولا دخل عليهم في شيء منه شكُّ

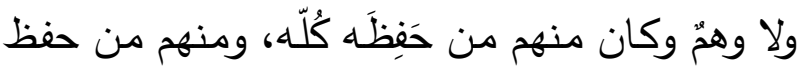

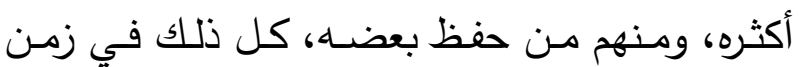

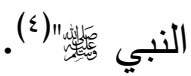
ثالثاً: تدوين القراءات الشاذة وأهم المصنفات فيها:

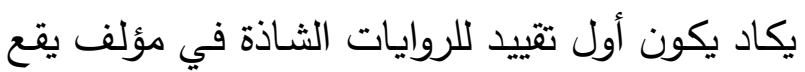
في كتاب "معاني القرآن" لمحمد بن المستتير قطرب

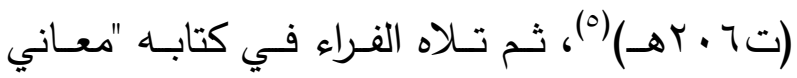

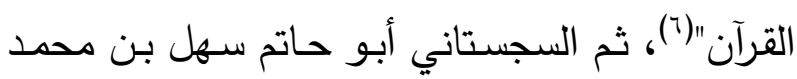

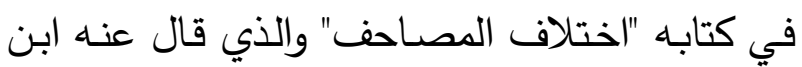
جني في المحتسب: "وروينا... في كتاب أبي علي محمد بن المستتير قطرب من هذه الثواذ صدراً كبيرا

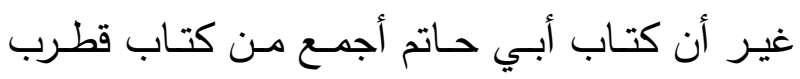

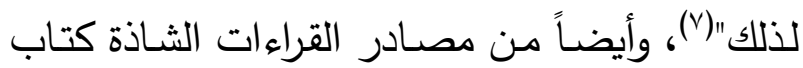
"معاني القرآن وإعرابه"( () للزجاج (ت • آسهـ)، وشواذ

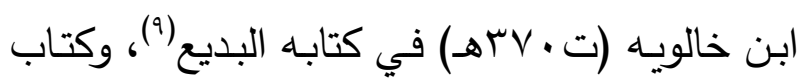
"المحتسب في تبيين وجوه شواذ القراءات والإيضـاح

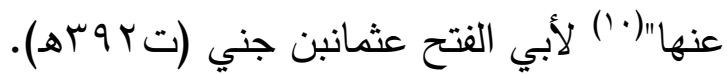
وفي القرن الخامس نشطت حركة التأليف في الثواذ

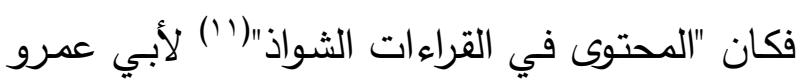

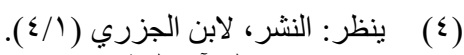

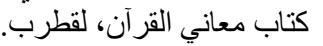
مطبوع، بتحقيق: د. عبدالفتاح إسماعيل شلبي، دار السرور.

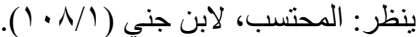
مطبوع، بتحقيق: د. عبدالجليل عبده شلبلي، دار الحديث، القاهرة.

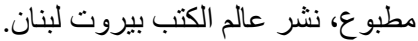

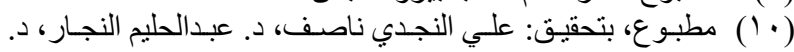

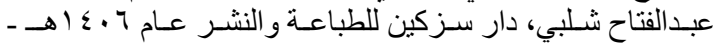
. 1919 (1') مخطوط، ذكره ابن خير الإنشبيلي في فهرسه (ص99)).
كذلك، فقد أقرأ رسول الله تواترت وإن لم تتعين بالثخص فكيف يسمى شاذًا؟

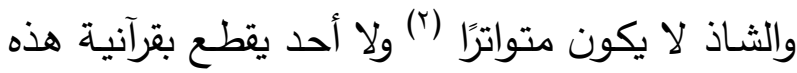
القراءات الثاذة خاصة بعد وصول القراءات المتواترة مقطوعًا بها. وبعد تحرير أقوال العلماء يتضـح "أن القراءة الثـاذة

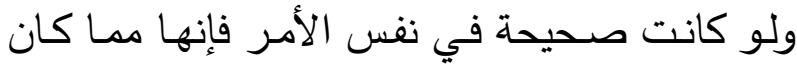

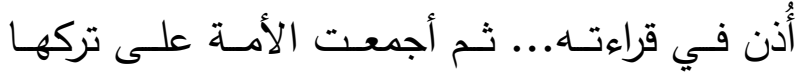
للمصلحة وليس في ذلك خطر ولا إثكال لأن الأمة معصومة من أن تجمع على خطأ"(").

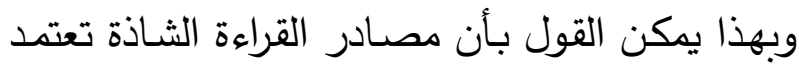
على ذاكرة الحفظة الذين سمعوها ممن قبلهم، ولم تحظً بالإجماع ولا النقل المتواتر فبقيت شـاذة يفاد منها في إثراء اللغة والتفسير والأحكام الثرعية. وحتى لا يتبادر إلى الذهن ذهاب شيء من القرآن

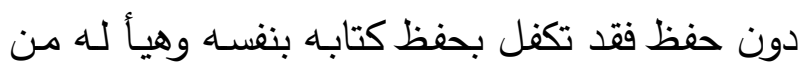
الرجال الأفذاذ من يقومون بهذا الدور تصديقًا لقولهـ تعـــــــالى : [الحجر: 9] ولهذا يقول ابن الجزري: "ولما خصَّ الله

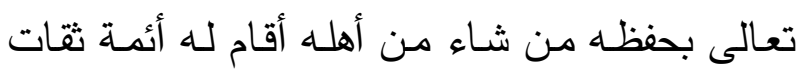
تجردوا لتصحيحه وبذلوا أنفسهم في إتقانه وتلقوه من لن النه

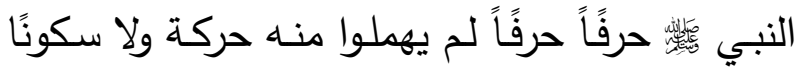

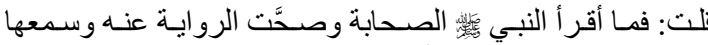

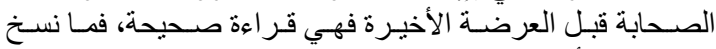

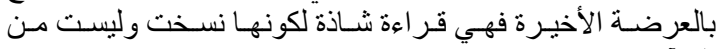
القرآن، فهي شاذة بهذا الاعتبار.

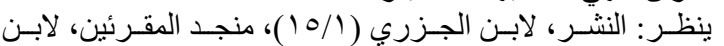

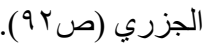
ينظر : منجد المقرئين، لابن الجزري (ص999). 
التأليف بالشـاذ ومـن أشهر المؤلفات كتاب "إتحاف فضـلاء البشر في القراءات الأربعة عشر "(·) للشيخ أحمد بن محمد بن أحمد الدمياطي المشهور بالبنا المتوفى سـنة (V l I ( اهـ)، وكتاب "القراءات الثـاذة وتوجيهرهـا مـن لغــة العـرب"(') للشـيخ عبـدالفتاح القاضي، وغيرها من الكتيات التي يحاول أصحابها اللحاق بمن سبقهم في تدوين هذه القراءات والعناية بها.

لابعاً: أعلام القراء في القراءات الثاذة: أما الأئمة ورواتهم من القراء في القراءات الشـاذة فهم:

1- الحسـن البصـري: أبـو سـعيد الحسـن بـن يسـار البصـري إمـام أهـل زمانـهـ علمـاً وعمـلاً (ت . 1 (هـ) ويروي عنه: أ- شــجاع بــن أبــي نصــر البلخـي البغـــادي . (ت . 19 (ته) ب- أ بـو عمـرو عيسـى بـن عمـر الثقفي النحـوي البصري (ت 9 ؛ اهـ). ץ- ابن محيصن: محمد بن عبدالرحمن بن محيصن السهمي مولاهم المكي (ت ب أه) ويروي عنه:

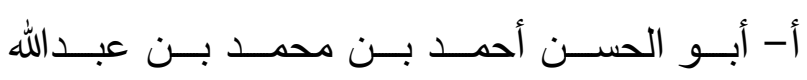

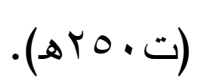

ب- محمــد بـن أحمــد بـن أيــوب بـن شــنبوذ

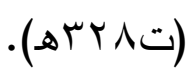

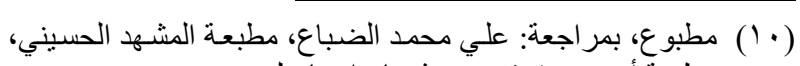

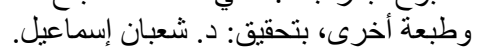
(11) مطبوع، دار إحياء الكتب العربية.
الداني (ت ع § §ه)، و"سوق العروس"(!) لأبي معشر

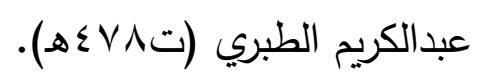

وفي القرن السادس كتب أبو محمد المعروف بسبط

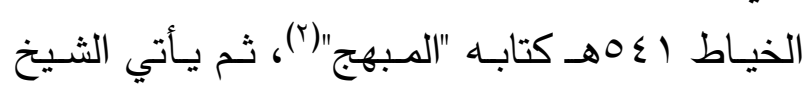
رضـي الـدين أبـو عبـدالله محمــــــن أبـي نصـر الكرماني في "شواذ القراءات"(־) فجمع مـا تقدم تأليفه

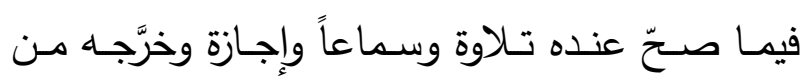
كتاب "اللـوامـح في شـواذ القـراءات"(؛) لأبـي الفضــل الرازي، و "سوق العروس" للطبري، و "الكامل"(ه) لابن

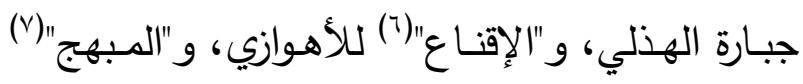

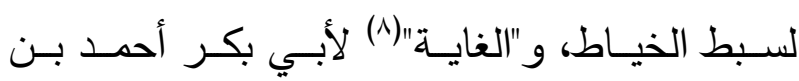

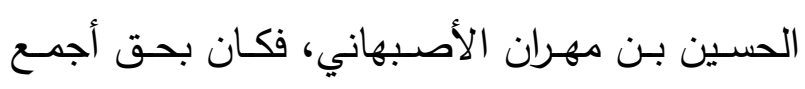
مؤلف للقراءات الشاذة. وفـي القـرن السـابع كـان كتــاب إعـراب القـراءات

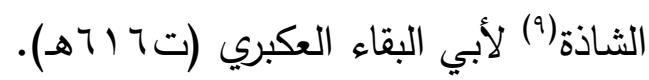
وهناك محاولات قليلة جداً في العصور المتأخرة في مخطوط في مكتبة برلين برقم pm403، وصـورة في دار الكتب

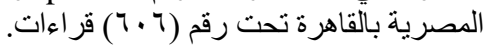

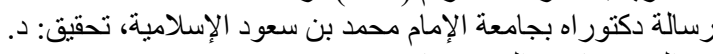

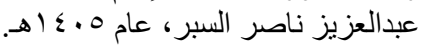

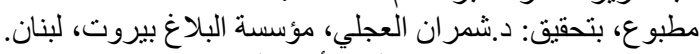

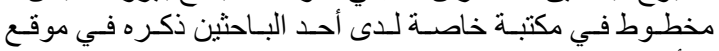
(الألوكة ـ المجلس العلمي-).

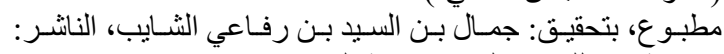

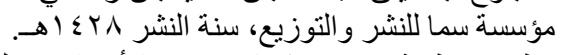

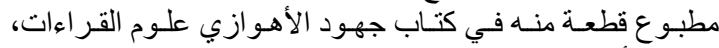

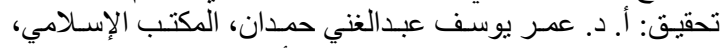

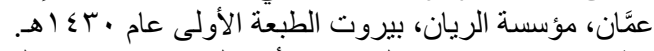

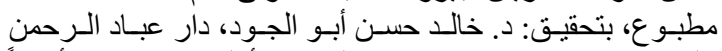

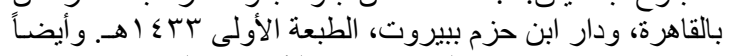

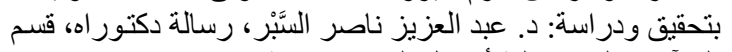

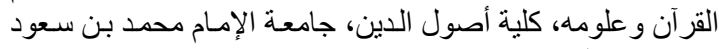
الإسلامية، الرياض،

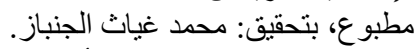
لبنان. مطبوع، بتحقيق: محمد السبد أحمد عزوز منباز، عـالم الكتب، بيروت، 
ب- الأعمش: سليمان بن مِهْرًان الأسدي بالولاء، أبو أولاًا: في الأحكام.

اختلف الفقهاء والأصوليون في الاحتجاج بالتراءات الثاذة في الأحكام على ثلاثة أقوال: القول الأول: لجمهور العلماء. ومفاده: أن القراءات الثاذة حجة في الأحكام، تنزيلا لها منزلة خبر الآحاد. وبـه قال أبو حنيفة (ت •.0 الهـ)، وقول للإمـام مالك

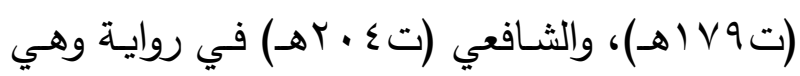

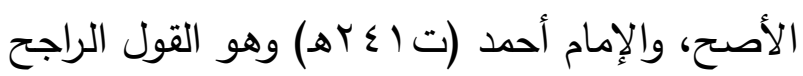
عنه.

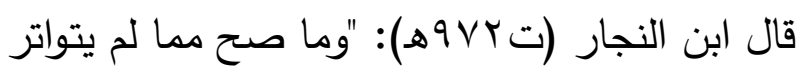

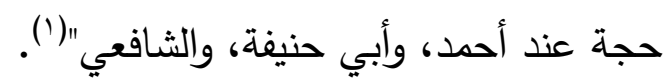
أدلتهم في ذلك: "أن المنقول بطريق الآحاد، إما أن

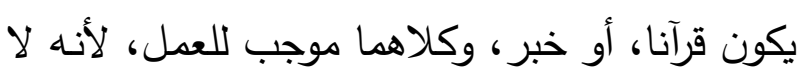

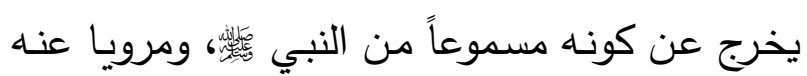
فيكون حجة"(r).

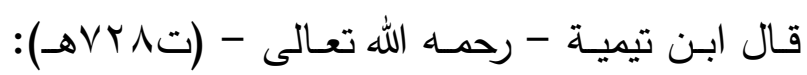
"ومثله احتجاج أكثر العلماء بالقراءات التي صحت تصديه عن بعض الصحابة، مع كونها ليست في مصحف

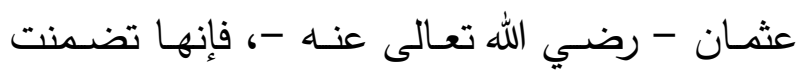

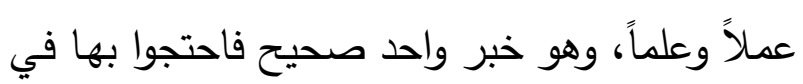

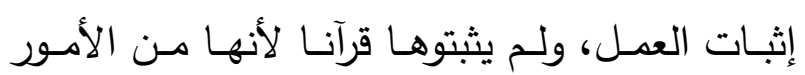
العلمية التي لا تثبت إلا بيقين"(r).

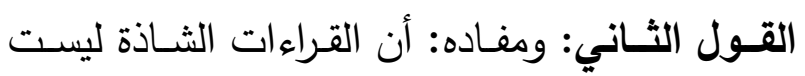

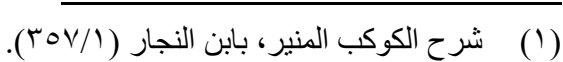

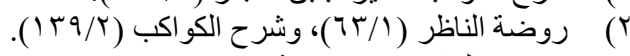

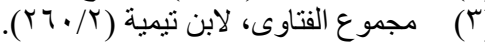

محمد الكاهلي مولاهم الكوفي، تابعي مشهور .

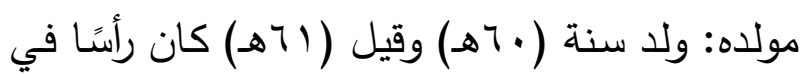
العلم النافع والعمل الصالح، وتوفي سنة (1 أهـ). وقراءته من روايتي:

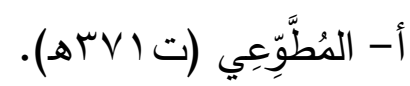

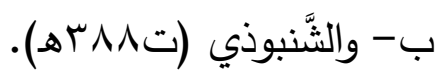
ع- يحي اليزيدي:أبو محمد يحيى بن المبارك بن

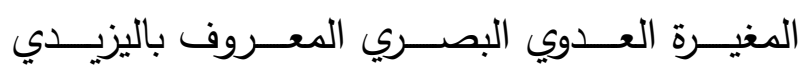

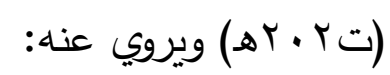

أ- أبو أيوب سليمان بـن أيـوب بـن الحكم الخياط

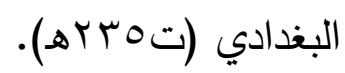
ب- أحمد بن فرح: هو أبو جعفر أحمد بن فرح بن جبريل البغدادي (ت بـ بـهـ). وقد انفردت القراءات الأربـع الثــاذ بالثـهرة دون غيرها، لأسباب منها: 1- لأنها قراءات متصل سندهاب مناء إلى أصحابها.

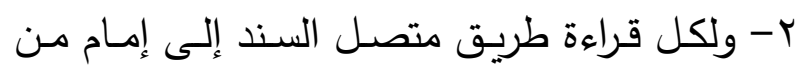
أئعة هذا الفن. r- ولكل إمام راويان، كما سبق. حكم الاحتجاج بالقراء ات الثاذة لمات

ومسـألة الاحتجـاج بـالقراءات الثـاذة مسـألة خلافيـة

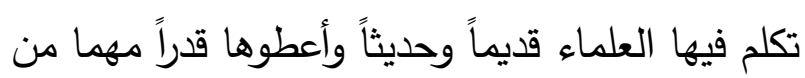
وقتهم ورأيهم، سوأ أكان في الأحكام الثرعية وثبوتها،

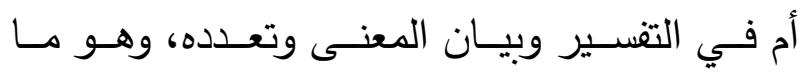
سنوضحه بإيجاز خلال هذا المطلب: 
علـى أنـــه قــرآن، والقــرآن لا يثبـــت إلا بـالتواتر

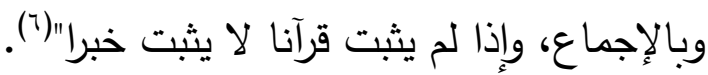

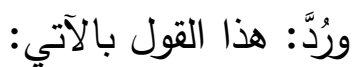
"بأن الناقل لهذه القراءة إنما نقلها سماعاً عن رسول بالئ الله

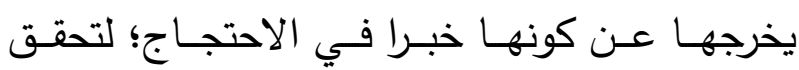

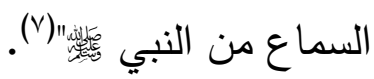
القول الثالث: أنها حجة إذا صرّح الراوي بالسماع أو بأنها قرآن، أو رفع ذلك إلى النبي إنها

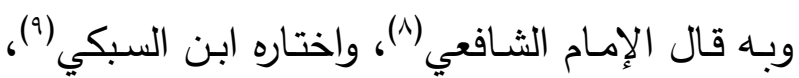

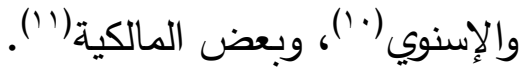

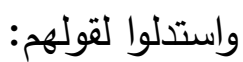

"بأنـه ممـا نـزل مـن القـرآن، وهذا وإن لم يكن قرآنَا

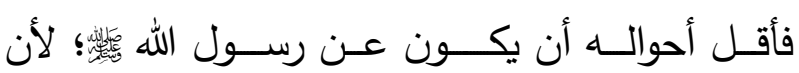
الترآن لا يأتي به غيره"(r'). اللرأي الراجح: هو رأي الجمهور القائل بحجية القراءة باءة الشاذة لقوة أدلتهم وضعف أدلة المانعين. مسألة هل تصح الصلاة بالقراءة الثاذة؟

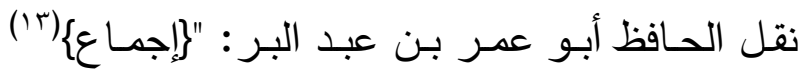

$$
\begin{aligned}
& \text { شرح الكوكب المنير ( ( } \\
& \text { القراءة الثشاذة، لمحمود صلاح (صن ـ (1). } \\
& \text { التمهيد، للإسنوي (ص (1) (1) ) }
\end{aligned}
$$

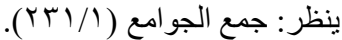

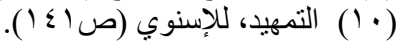

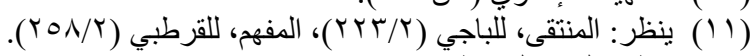

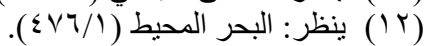

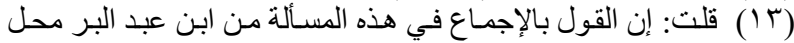

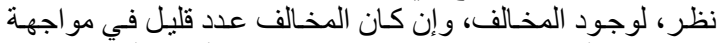

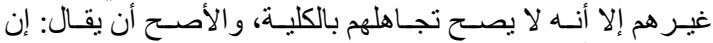

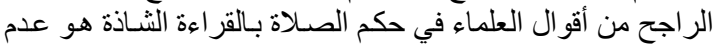

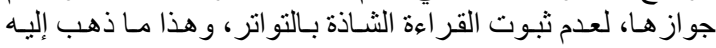

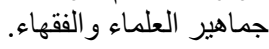

حجة في الأحكام الشرعية.

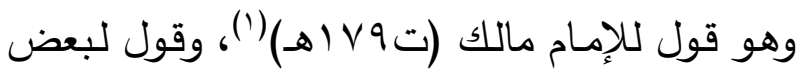

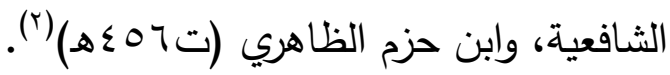
أدلتهم في ذلك: "أن الراوي نقله آحاد، فإنْ ذكره على أنـه قرآن فهو

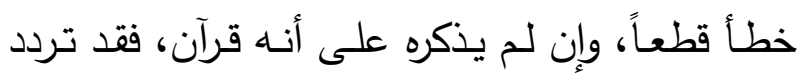

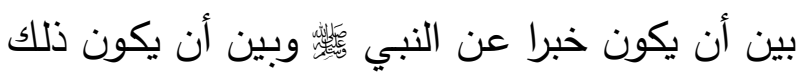
مذهبا له، فلا يكون حجة" لَ"). وقد رُدّ هذا القول من عدة وجوه، منها:

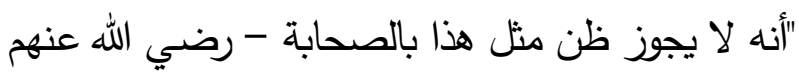
-، فإن هذا افتراء على الله تعالى وكذب عظيم؛ إذ جَعَل

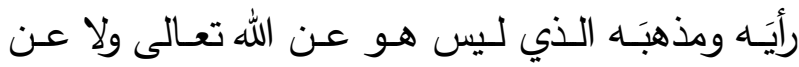

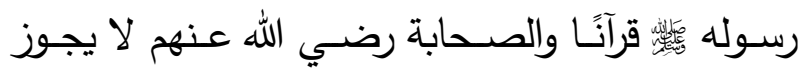

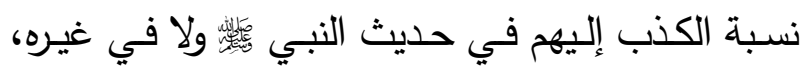

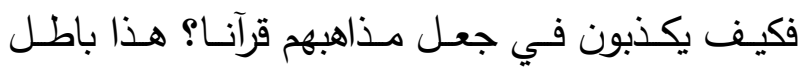

يقينًا"(i) - قال ابن العربي في القبس:

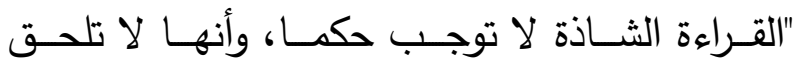

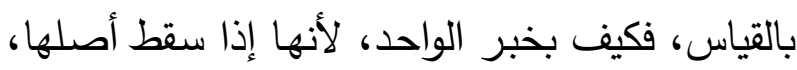

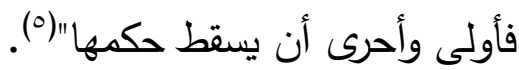
- وقال النووي (ت • 79 هـ):

$$
\begin{aligned}
& \text { (1) منتهى الوصول والأمل في علمي الأصول والجدل، لابن الحاجب } \\
& \text {. ( }(7 / 1)
\end{aligned}
$$

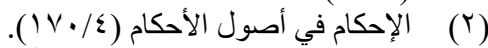

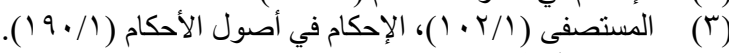

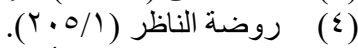

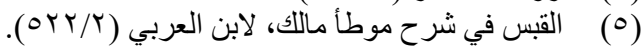




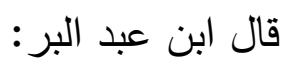

"قال أبو عمر : قد احتج مالك في هذا الباب لمعنى

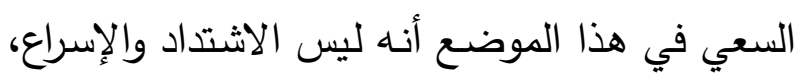

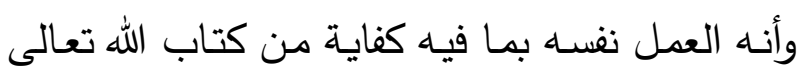

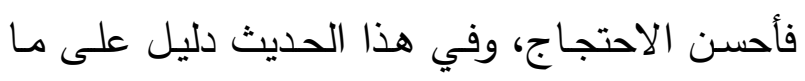

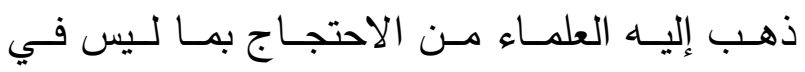

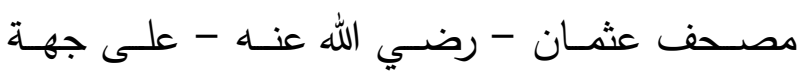

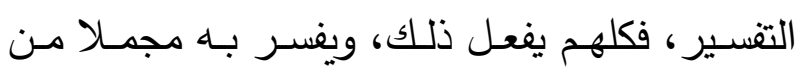

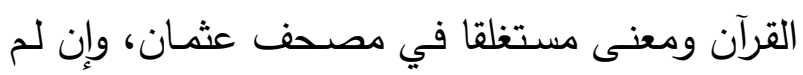
يقطع عليه بأنه كتاب الله تعالى، كما يفعل بالسنن

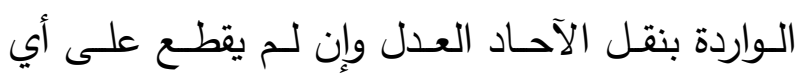

منها"("). (1)

الثاني: القول بالمنع ومن هؤلاء الرازي في تفسيره

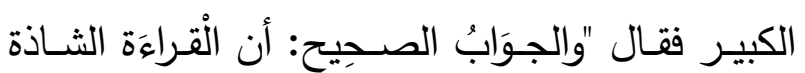
هردودة لِأن كُل مَا كان قرَّآنا وجب أَن يَتُبت بِالتواتُر

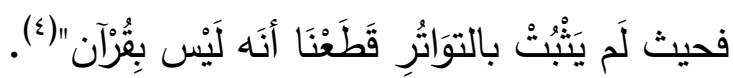

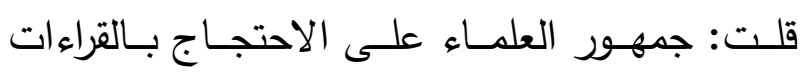

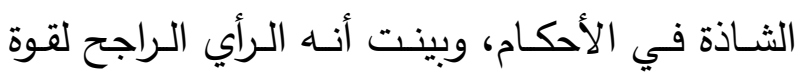

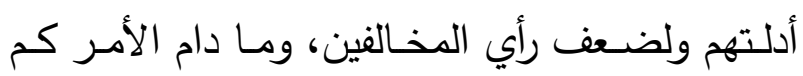
ذكر ، فالأولى الاحتجاج بها في التفسير ، لأنها قد الأد

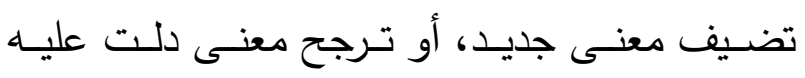

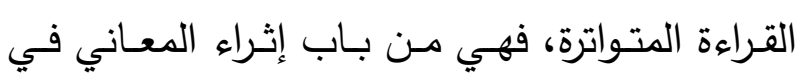

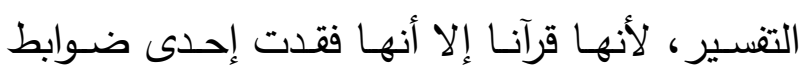
القراءة المتواترة، وإذا لم تكن من تفسير القرآن بالقرآن

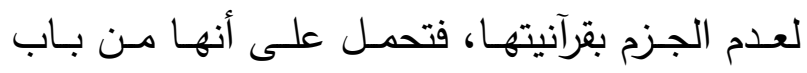

المسلمين على أنه لا تجوز القراءة بالثـاذة، وأنه لا يصلى خلف من يقرأ بها"(') ثانياً: في التفسير. الاحتجـاج بالقراءات الثـاذة في التقسير ، مسألة شد وجذب بين العلماء، كما سبق في الاحتجاج بها في الاهي

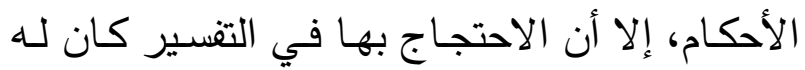
تنفيذ عملي واقعي في كتب أعـلام المتقدمين مـن الاحن المفسرين ولذا يمكن أن نجمل القول في هذه المسألة فيما يأتي: انقسـم العلمـاء فـي الاحتجــاج بـالقراءة الثـاذة في يـي التفسير إلى قولين: الأول قــول الجمهــور: على الاحتى الاحتبـاج بـالقراءات الثاذة في التفسير، وقد احتج بها جمهور العلماء بدأ

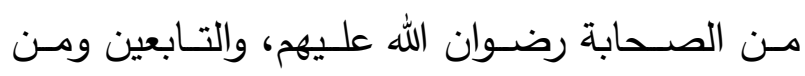
بعدهم(r)، واحتج بهـا في التفسير أعـام المفسرين ولهن منهم: شيخ المفسرين ابن جرير الطبري (ت • آسهـ) في

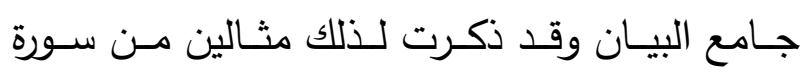
إبراهيم، ويوسف - عليهما السلام - فيما سبق، وابن عطية (ت ؟ـهــ) في المحرر الوجيز ، والزمخشري

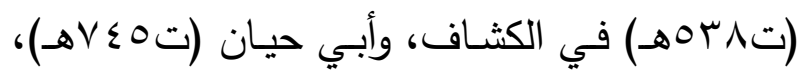
والقرطبي في الجامع لأحكام القرآن، وابن الجوزي في

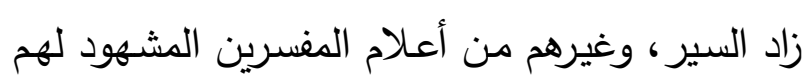

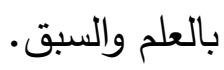

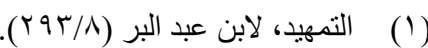

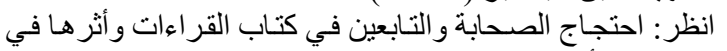




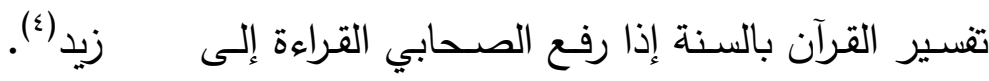
رسول الله

أخذ القراءة عنـه عرضــا محمد بـن صـالح بـن زيـــ

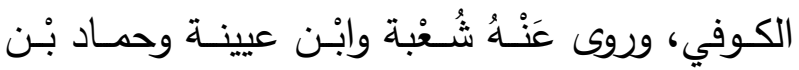

أقوال العلماء فيه:

كان ثقـة روى عنـه شـعبة(؟) حدثنا عبد الرحمن أنـا عبد الله بن أحمد بن حنبل فيما كتب إلي قال سئل أبي عن أبان بن تغلب فقال: ثقة، حدثنا عبد الرحمن ثنا محمد بن سعيد المقرئ قال سمعت عبد الرحمن بن الحكم بن بشير بن سلمان يذكر عن أبان بن تغلب صحة حديث وأدب وعقل سمعت أبى يقول: أبان صـالح(V) قـال أبو جعفر : هو ثقة جليل القدر عظيم المنزلتة في أصحابنا لقي أبـا محمد علي بن الحسين وأبا جعفر وأبا عبد الله وروى عنهم، وكانت له عندهم حظوة وقدم، قال لله أبو جعفر : اجلس في

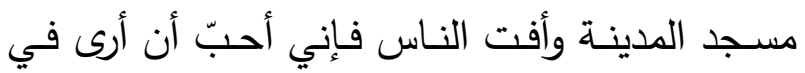
شيعتي مثلك، وقال أبو عبد الله لمـا أتاه نعيـه: أمـا والله لقد أوجع قلبي موت أبان قال: وكان قارئا فقيها لغويـا نبيهـا تبدّى وسـدع مـن العـرب وحكى عنهم وصنف كتاب الغريب في القرآن وذكر شواهده من الشعر، فجاء فيما بعد عبد الرحمن بن محمد الأزدي الكـوفي فجمـع مـن كتـاب أبـان ومحمـد بـن السـائب الكلبي وأبـي روق عطيـة بـن الحسارث فجعلـه كتابـا أنهـا تفــير القـرآن بـأقوال الصــابة، أو بـأقوال التابعين، الذي هو نوع من أنواع التفسير بالمأثور (') وفي تأكيد هذا المعنى يقول الإمام القرطبي: "أنه وإن لم يثبت كونه قرآنا فقد ثبت كونه سنة، وذلك يوجب العمل كسائر أخبار الآحاد"(r). المطلب الثالث

التعريف بالإمام أبان بن تغلب من حيث مولاه، ونشأتها،

\section{وشيوخه، وتلامذته، وأقوال أهل العلم فيه،}

\section{ومؤلفاته، ووفاته}

هو الإمام أبان بن تغلب الربعي أبو سعد ويقال أبو أميمـة الكوفي النحوي جليل، قرأ على عاصـم وأبي الهي عمرو الشيباني وطلحة بن مصـرف والأعمش وهو أحد الذين ختموا عليه ويقال إنه لم يختم القرآن على الأعمش إلا ثلاثة منهم أبان بن تغلب، أخذ القراءة عنه عرضا محمد بن صالح بن زيد الكوفي (r). شيوخه: قرأ على عاصـم وأبـي عمرو الثـيباني وطلحة بـن مصرف والأعمش وهو أحد الذين ختموا عليه ويقال إنه لم يختم القرآن على الأعمش إلا ثلاثة منهم أبان بن تغلب، سَمِحَ الحكم وفضيل بْن عَمْرو وأبِا إِنْحَاق

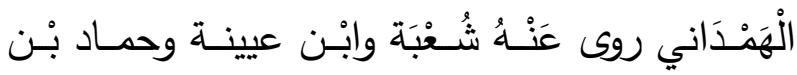

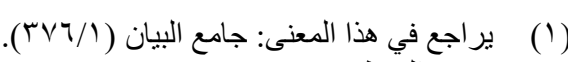

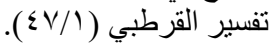

$$
\begin{aligned}
& \text { غاية النهاية في طبقات القراء ( (/؟) }
\end{aligned}
$$




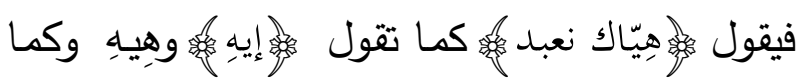
تقول

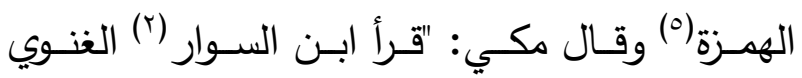

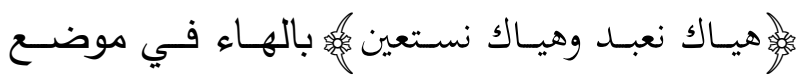
الهمزة، وهي لغة قليلة، أكثر ما تقع في الشعر"((؟). أثرها في التفسير:

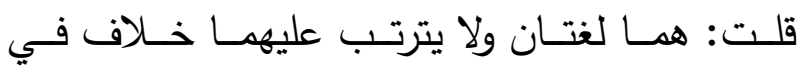
المعنى، فتقول: "

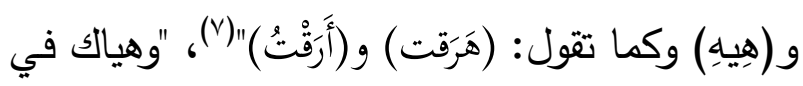

الموضعين لغة مشهورة"(^) ثانياً: سورة البقرة:

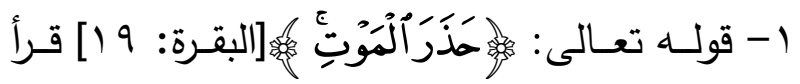

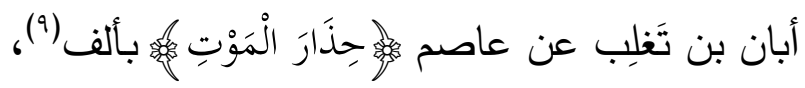

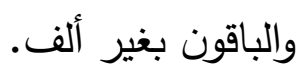

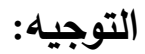

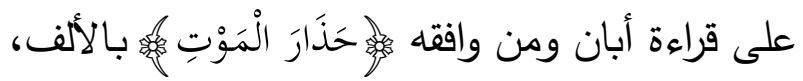

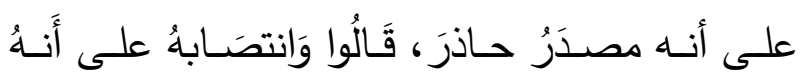

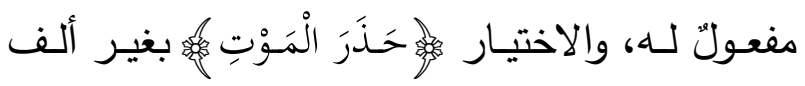

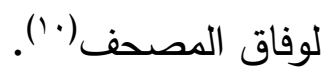

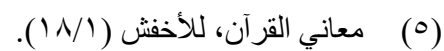

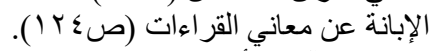

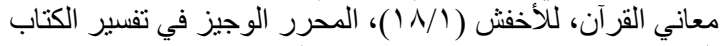

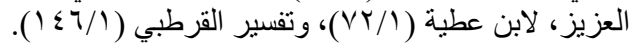

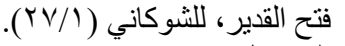

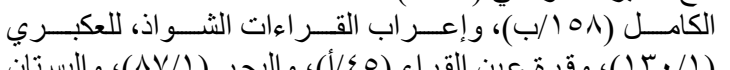

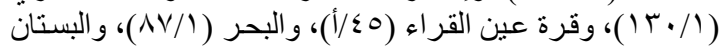

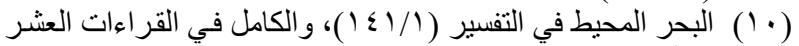

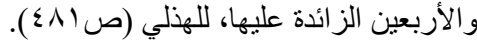

واحدا وبيّن مـا اختلفوا فيـهـ ومـا اتفقوا عليه، فتـارة يجيء كتاب أبان مفردا، وتارة يجيء مشتركا على ما واهي عمله عبد الرحمن. ولأبان أيضا كتاب الفضائل (').

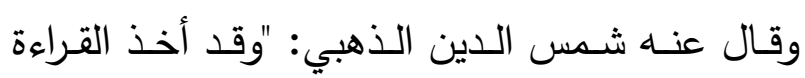
عرضـا عن عاصم، وطلحة بن مصرف وتلقى من

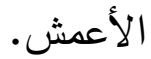
وحديثه نحو من مائة حديث، وهو صدوق في نفسـه

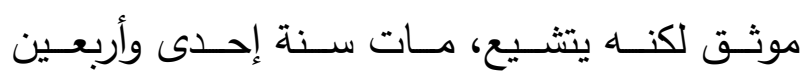

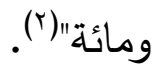

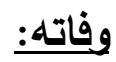

توفي سنة إحدى وأربعين ومائة وقال القاضي أسد: سنة ثلاث وخمسين ومائة (†). المبحث الثاني

(ما وافق فيه أبان بن تغلب القراءات المتواترة، أو

خالفها)

\section{أولاً: سورة الفاتحة:}

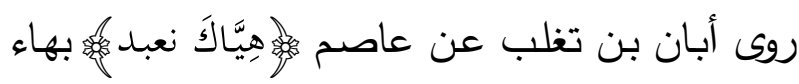

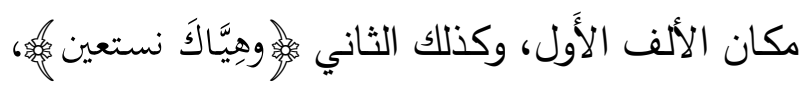

وفي جميع القرآن (ई).

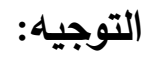

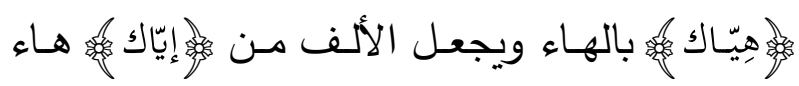

$$
\begin{aligned}
& \text { معجم الأدبـاء = إرشــاد الأريـب إلىى معرفـة الأديـب، للحمـوي }
\end{aligned}
$$

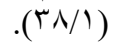

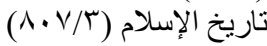

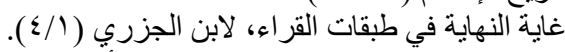

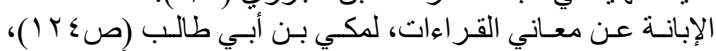

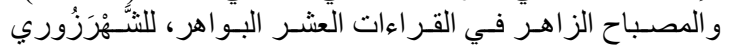

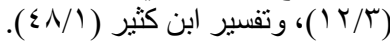


لالتِقَاءِ الساكِنين ههنا خطأ وأنه يلزم من قال هذا أن

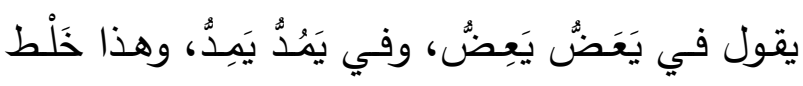

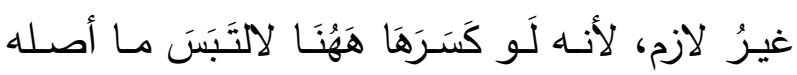

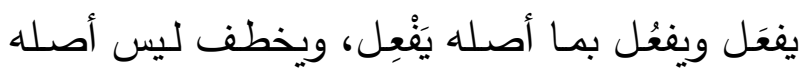

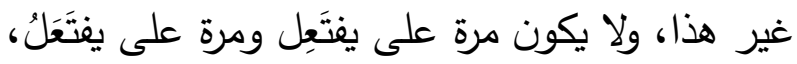

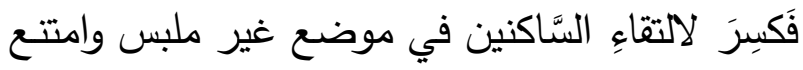

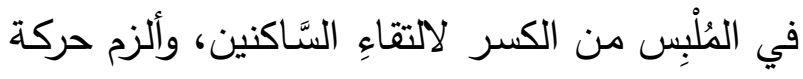

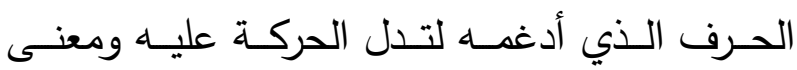

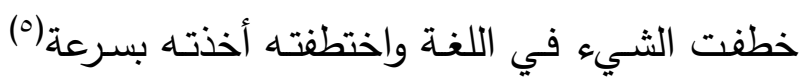

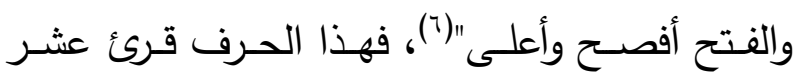
قراءات: السبعة يَخْطَفُ، والثَواذ: يَخَطِفُ يَخْنَطِنُ

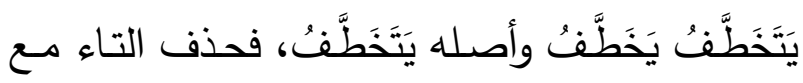
اليـاء شـذوذا، كمـا حذفها مـع التـاء قياسـا يخطف

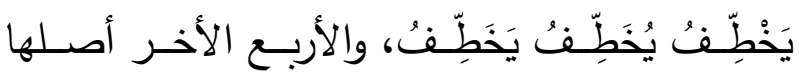
يُخْنَطَفْ فعرض إدغام التاء في الطاء فسكنت التاء

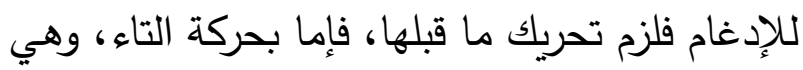

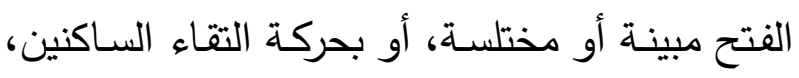

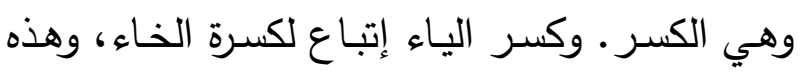

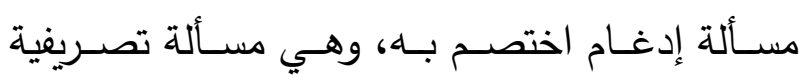

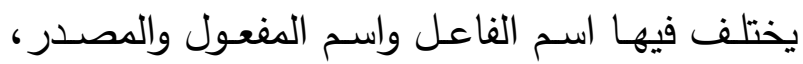
وتبيين ذلك في علم التصريف(V). أثرها في التفسير:

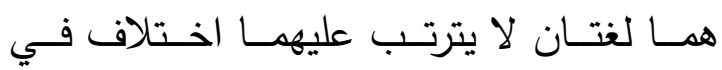

معاني القر آن و إعر ابه، للزجاج ( (90/1).

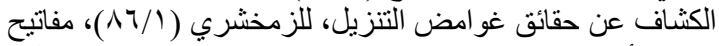

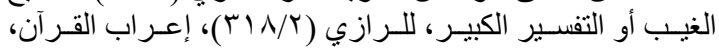

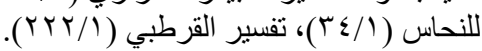

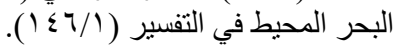

\section{أثرها في التفسير:}

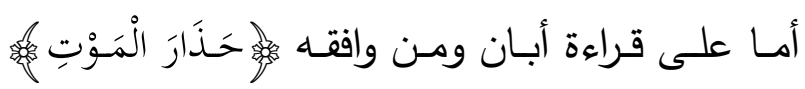

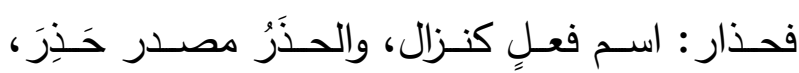
والحِذارُ مصدر حاذَرَ (') وأمـا على قراءة الجمهور

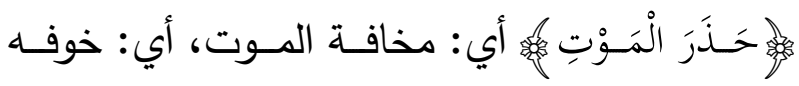

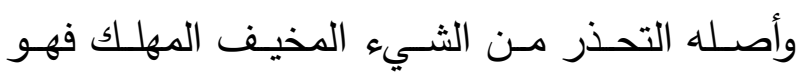
أخص من الخوف، يقال: حذر يحذره حذراً وحذراً، وقيل: الحذر بالكسر : الاسم(؟).

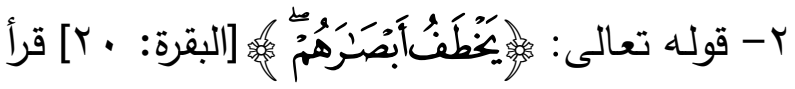
أَبَان بن تغلب، وأَبَان بن يزيد كلاهما عن عندم عاصم بفتح الياء، وسكون الخاء، وكسر الطاء مخففاً (r).

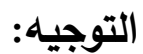

قال الأخفش: "فمنهم من قرأ زُ جه دِ زَ من "خَطَفَ"

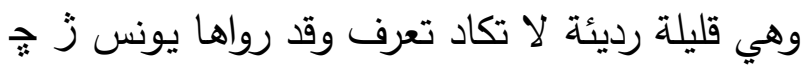

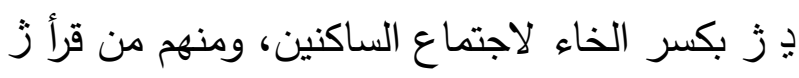

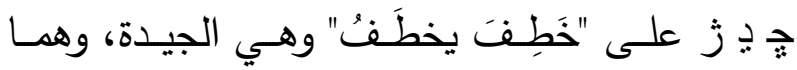

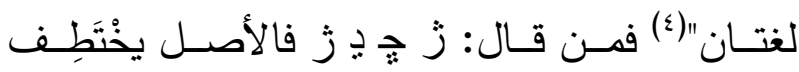

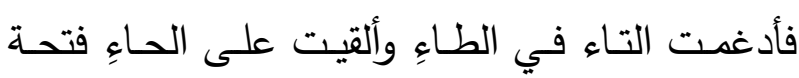

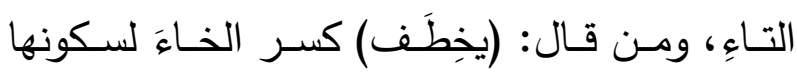

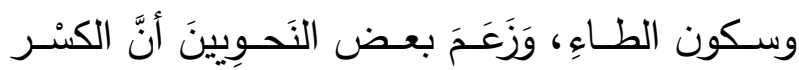

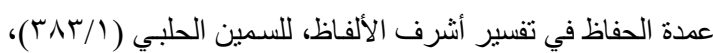

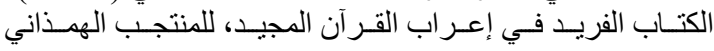
( ( $\vee \vee \wedge / 1)$

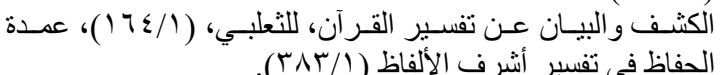

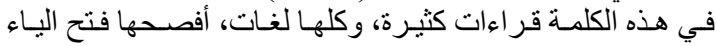

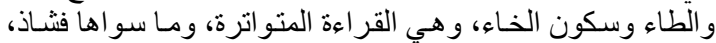

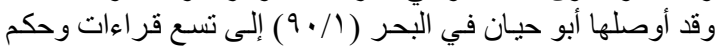

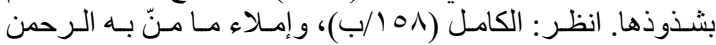

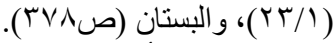

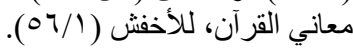




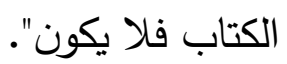

وقـال غير عطـاء: 》معنىى" 》أو ننسـأها《: نؤخرهـا عن النسـخ إلى وقت معلوم، مـن قولـه: نسـأت هذا

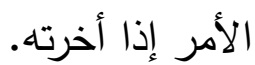

وعلى قراءة الباقون السـين، مـن غيـر همـز، مـن النسـيان الذي بمعنى الترك أي نتركها فـلا نبـدلها، ولا ننسـخها، قالـه ابـن عباس - رضـي الله عنه - والسـدي، وقال الزجاج: واللذي عليـه أكثر أهل اللغـة والنظر أن معنى 》أو ننسـهاه نـبح لكم تركها، مسن نسـى إذا تركيه. اهـ. وقيل: النسيان على بابه الذي هو عدم الذكر، على معنى أو ننسـكها يـا محمد فـلا تذكرها، نقل بـالهمز

فتعدى الفعل إلى مفعولين (०).

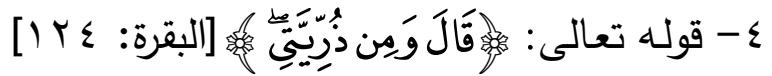

قرأ أبان بن تغلب بكسر الذال في جميع القرآن(؟).

\section{التوجيه:}

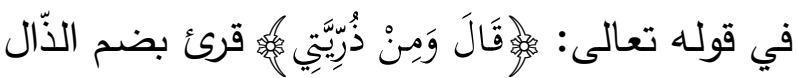
وفتحها وكسرها، فأمـا قراءة الضـم فقرأ بها السبعة، ووجهها أنها تحتمل أن تكون مشتقِّة من ذَرَبْتَ، أو من ذَرَوْت لغـة في ذريــ، أو من ذراً الله الخلق، أو

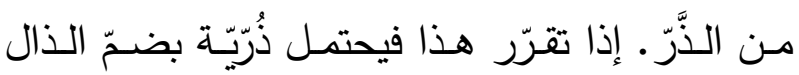

الأوّلِ: أن تكـون "فُعُولـة" مـن ذرأ الله الخلق، الأصسل

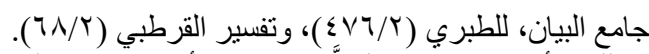

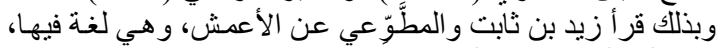

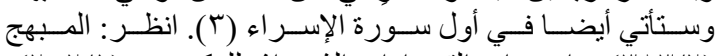

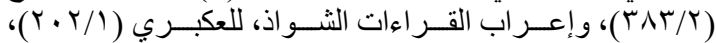

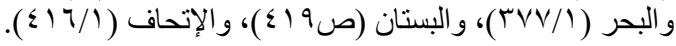

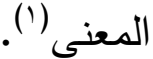

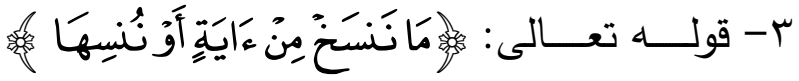
[البقرة: 7 ـ 1 ] قرأ أبو عمـرو وابـن كثير وأبَان بـن

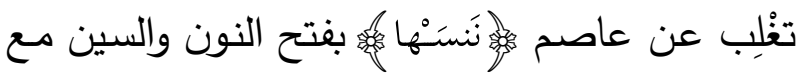

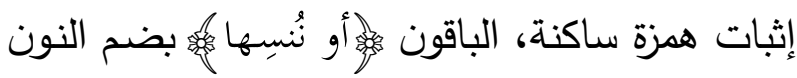
الأولى وكسر السين من غير همز (ז).

\section{التوجيه:}

قولـه تعـالى: وبضمها وترك الهمز فالحجة لمن فتح النون وهمز: أنـهـ جعلـه مـن التأخير ، أو مـن الزيـادة ومنـه قولهم: (نسـأ الله أجلك وأنسـأ في أجلك) والحجـة لمـن ضـمّ وترك الههـز : أنـهـ أراد: التـرك يريـد: أو نتركهـا فـلا

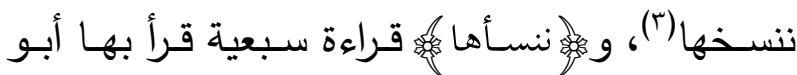
عمرو وابن كثير ، ونسبت إلى عمر بن الخطاب رضي الله عنه -، وابن عباس، وعطاء بن أبي رباح ومجاهد، وإبراهيم النخعي، وعبيد بن عمير (؛). أثرها في التفسير:

على قراءة ابن تغلب ومن وافقـه النـون الأولـى، والسـين، وهمـزة سـاكنة بـين السـين والهمـزة، مـن (النسـأ) وهـو التأخير، قـال عطـاء بـن يسـار : "أي نـؤخر نســخ لفظهـا، أي نتركــهـ فـي أم

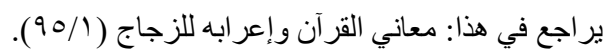

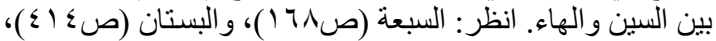

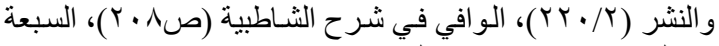

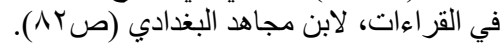

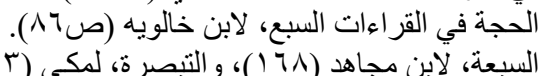

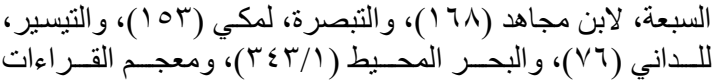


تََرََّنُتُ، وأدغمت الياء في الياء.

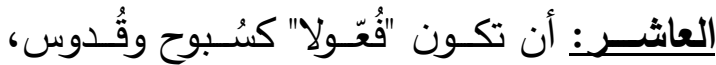

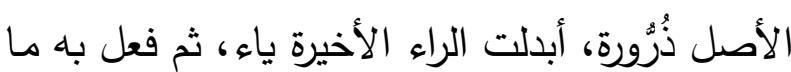
تقدَّم من الإبدال والإدغام وكسر الراء.

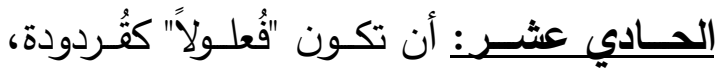

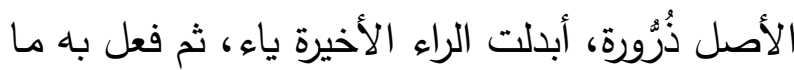
تقدّم من الإبدال والإدغام وكسر الراء. وأما قراءة الكسر فقرأ بها زيد بن ثابت، ووجهها لإدهاء أنها تحتمل أوجها:

الأول: أن تكــون "فِقِيـــة" مـن ذرأ الله الخـــق،

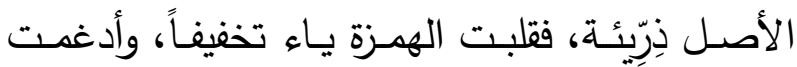

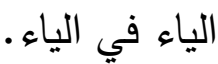

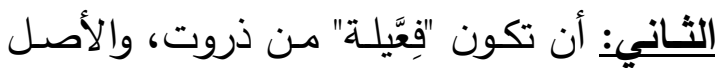

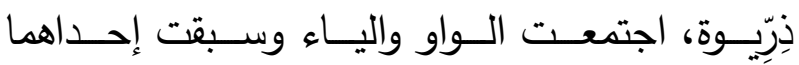
بالسكون، فقلبت وأُدغم.

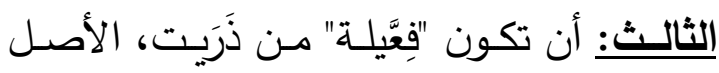
ذِرَّيية، فأدغمت الياء في الياء.

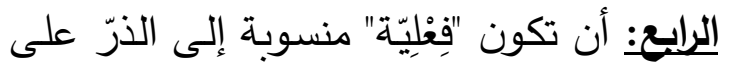

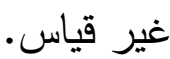

الخـامس: أن تكون "فِعليّة" من الذَّرّ، والأصل فيل

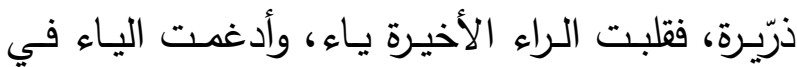
الياء. الســادس: أن تكـون "فِعليــة" كِلتيــت، وهـو

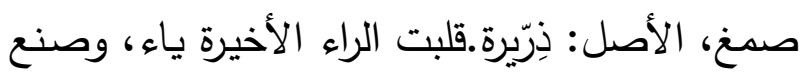

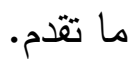
فهذه سبعة عشر وجهاً:مع ضمّ الدال أحد عشر
ذُرُوهة، فُقُلبت الهمزة ياء، صار ذُرْوية، اجتمعتا الواو

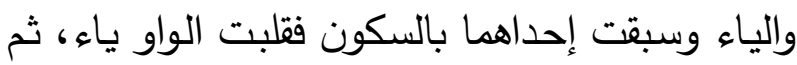
أدغمت الياء في الياء، وكسرت الراء لأجل الياء.

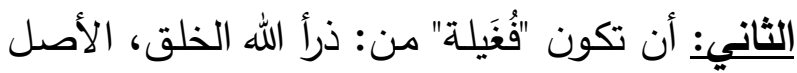

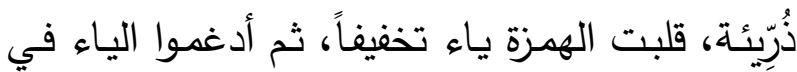
الياء. الثالث: أن تكون "فُعْولة" من ذَرَوْت، الأصل ذُزُووة،

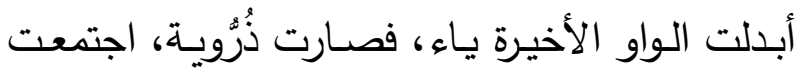
الياء والواو وسبقت إحداهما بالسكون، فصنع به ما تقدّم من قلب الواو ياء وإدغام الياء في الياء، فصار ذُْْيّة، ثم كسرت الراء لأجل الياء بعدها.

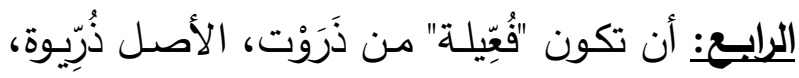
اجتمعت الواو والياء وسبقت إحداهما بالسكون، قلبت الواو ياء، وأدغمت الياء في الياء، فقيل ذُرِّيّة.

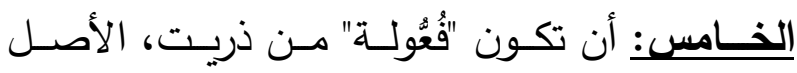

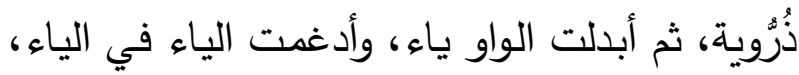

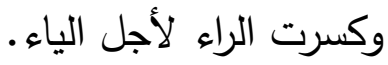
السـادس: أن تكون "فُعِيّة" من ذريت، الأصل ذُِِّيِة، وأدغمت الياء في الياء. السـابع: أن تكون "فُعْليّة" من الذّرّة ، وهو مفرد

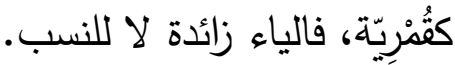

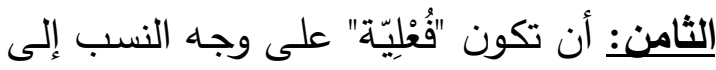

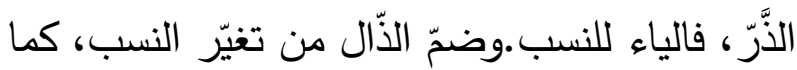
قالوا في النسب إلى الدَّهْر : دُهري.

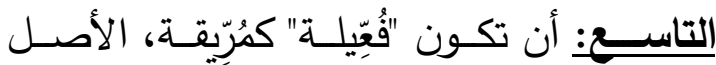

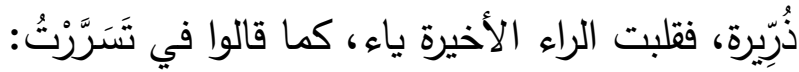




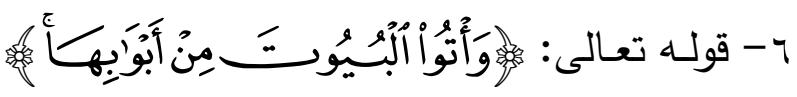
[البقرة: 19 1)] قرأ أبَانُ بن تغْلب والمفضَّل طريق أبي

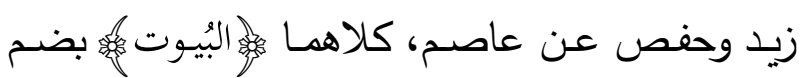

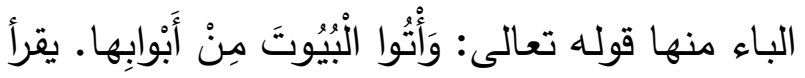
وما شاكله من الجموع بالضم والكسر (v).

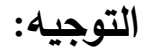

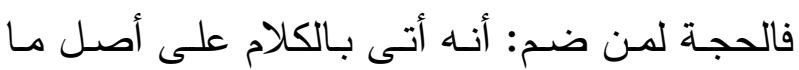

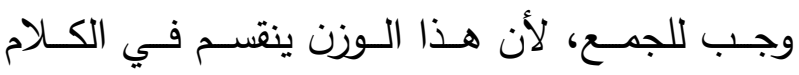
قسمين: جمعا كقولك: (فلوس) ومصدرا كقولك: (قعد هد هون

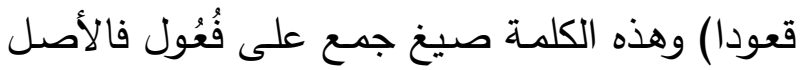
فيها أن ينضم الفاء، والحجة لمن كسر : أنه لـا كان

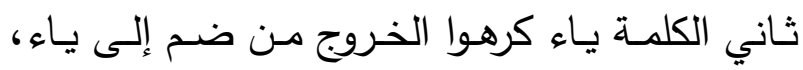

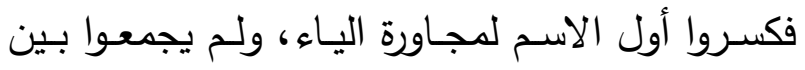

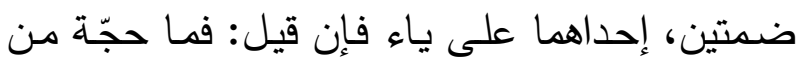
ضم العين من (العيون) والجيم من (الجيوب) وكسر

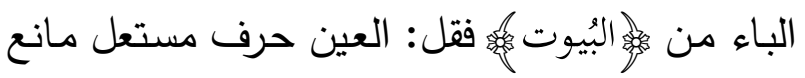
من الإمالـة، فاستتقل الكسر فيـه فبقّاه على أصلـه،

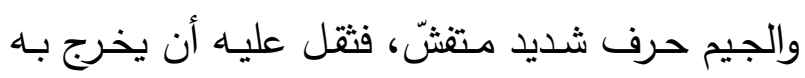
من كسر إلى ضم، فأجراه على أصله، والحجة لمن لن كسر الباء كثرة استعمال العرب لذلك، وهم يخفقون ما يكثرون استعماله: إمّا بحذف، وإمّا بإمالة، وإِّا بتخفيف. ودليل ذلك إمالتهم (النار) لكثرة الاستعمال، وتفخيم (الجار)، لقلة الاستعمال (^).

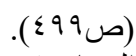

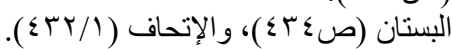

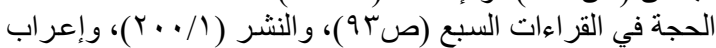

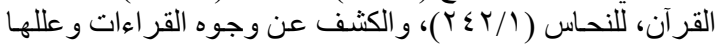

وجهاً، ومع الكسر ستة (1). - (1)

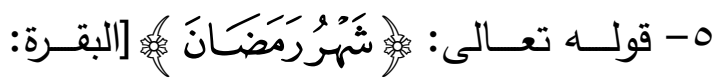

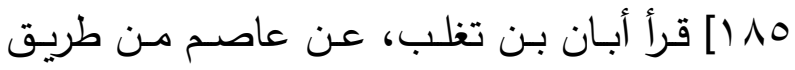

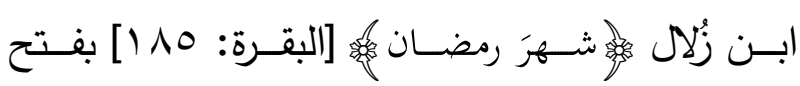

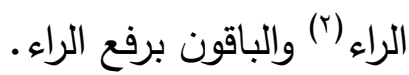

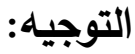

قرأ الجمهور : (شهرز) ) بالرفع، على أنه خبر ابتداء مضمر ، أي ذلك شهر (r).

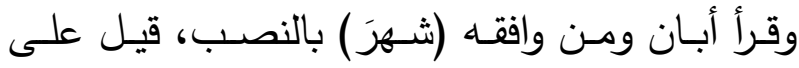
الإغراء، وقيل على الظرف، وذهب بعضهم إلى أنه

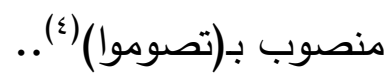

\section{أثرها في التفسير:}

أما على قراءة أبان بن تغلب ومن وافقهـ

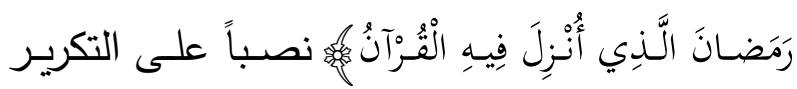
م

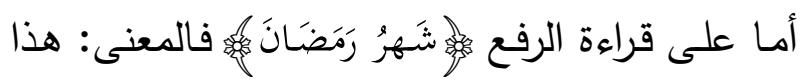

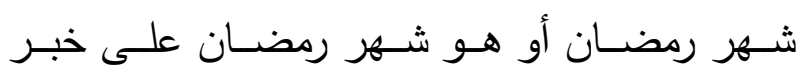

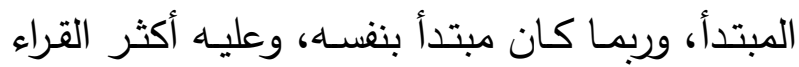

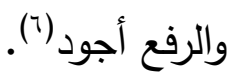

تحفة الأقران في مـا قرئ بالتتليث من حروف القرآن، للرعيني

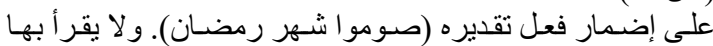

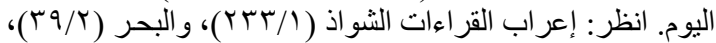

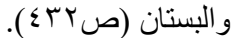

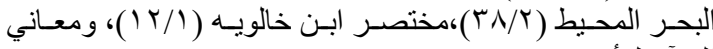

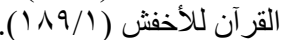

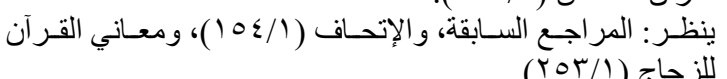

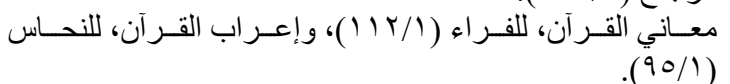
الكامـل فـي القـر اءات العشـر والأربعـين الزائدة عليهـا، الهـلـي 


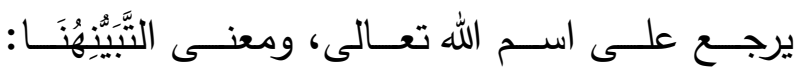
الإيضاح) (£)

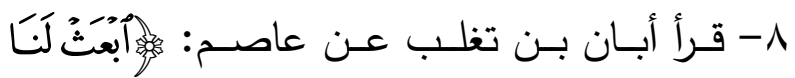

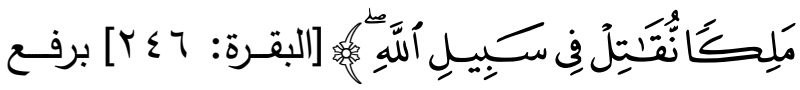
النام (0)

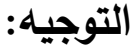

أما على قراءة ضم اللام على الاستئناف أو الحالية، وهي قراءة شاذة، وعلى

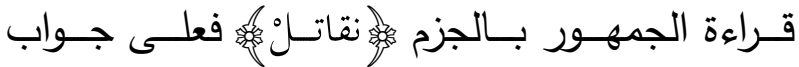

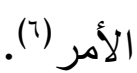

\section{أثرها في التفسير:}

على قرأة الجزم (نقاتلن) فهي على الجـواب للطلب أي: (إبعث)، وعلى قراءة الرفع فهي على الصفة لما قبله وهو (ملكا) (v)

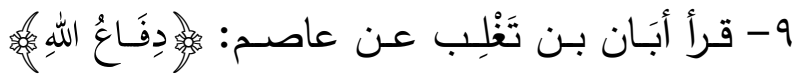
[البقرة: 1Y01] بكسر الدال مـع إثبات الألف، ومثله

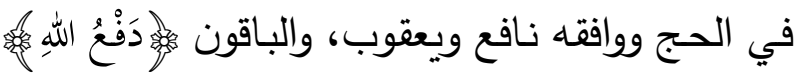
بغير ألف مع فتح الدال(^).

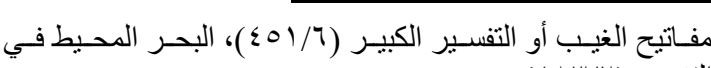

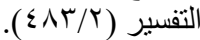

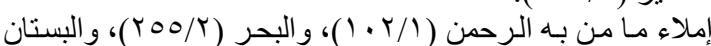
. (ص ( ) المصادر السابقة عن

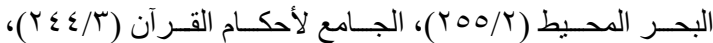

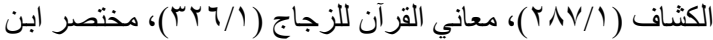

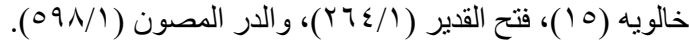

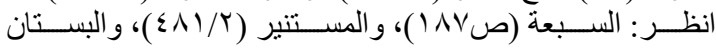

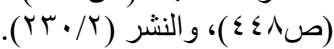

أثرها في التفسير:

قراءة ضـم الباء من (البيوت) على الأصل، وقراءة كسر البـاء لمناسـبة اليـاء قبلها وهمـا لغتان بمعنى

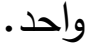

- قوله تعالى : V

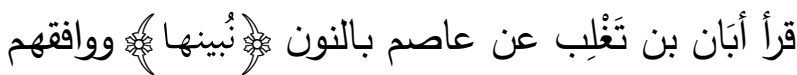
أبو عمرو ونافع، والباقون بالياء (').

\section{التوجيه:}

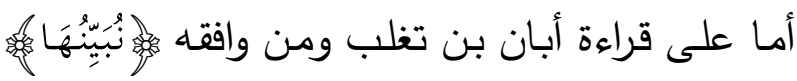
"بـالنون على طريـق الالتفـات، ومعنـى التبـين هنـا: الإيضاح، وخص المبين لهح بالعلم تشريفا لهم، لأنهم الذين ينتفعون بما بين الله تعالى من نصب دليل على ذلك مـن قـول أو فعـل، وإن كـان التبـين بمعنى خلق البيان، فـلا بـ من تخصيص المبين لهم الذين يعلمون بالــكر ، لأن مـن طبـع على قلبـه لا يخلـق فـي قلبـــ

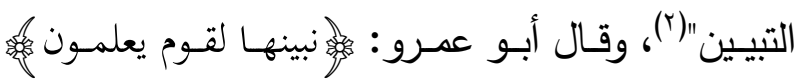
بالنون، والوقف عليه على هذه القراءة أكفى منه على قراءة من قرأ بالياء، لأن ذلك راجع إلى اسم الله- عز وجل - المتصل به (r). أثرها في التفسير:

فعلى قرأ عاصم في رواية أبان (نُبَّنُهَها) بالنون وهي نون التعظيم،على طريق الالتفات، وبالياء على أنه

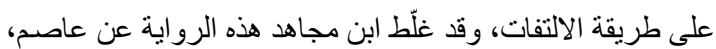

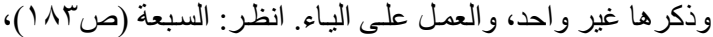

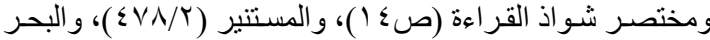

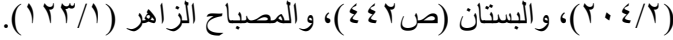

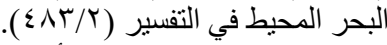
المكتفى في الوقف والابتداء، لأبي عمرو الداني (صبr). 


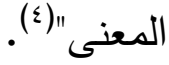

• 1 قرأ أبان بن تغلب، وحمزة في قوله تعالى:

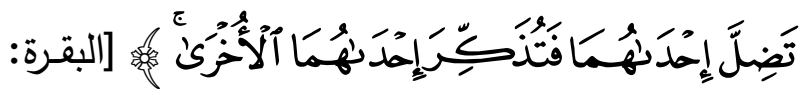

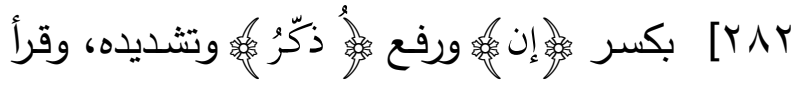

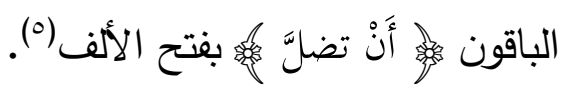

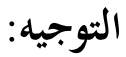

أما على قراءة أبان بن تغلب ومن وافقه بكسر همزة

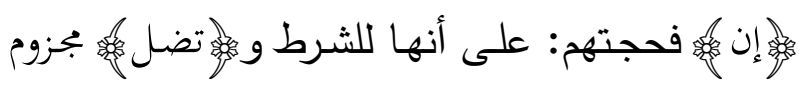

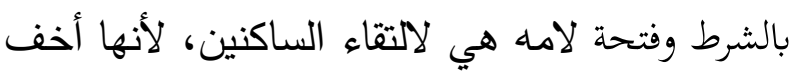
الحركات، وجعل الفـاء في قولـه:

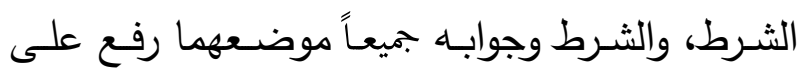

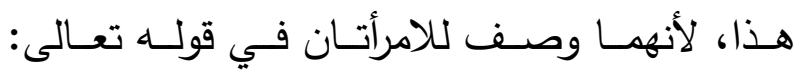

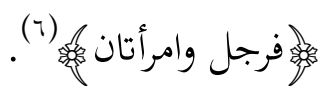

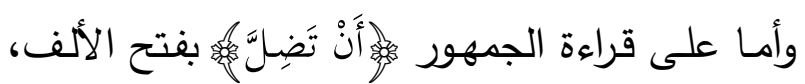

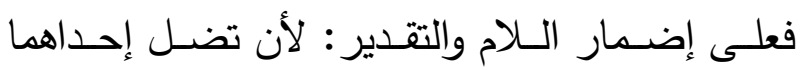

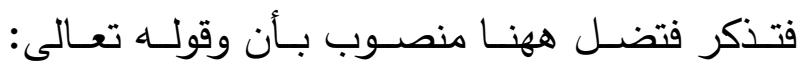

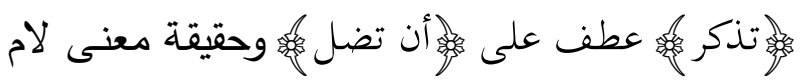

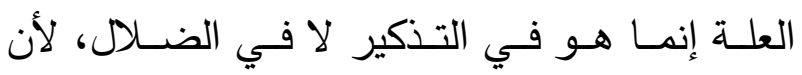

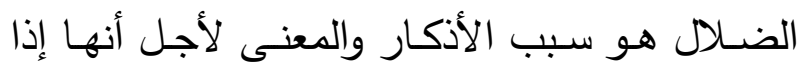

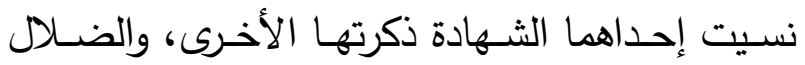
هاهنا: النسيان (v)

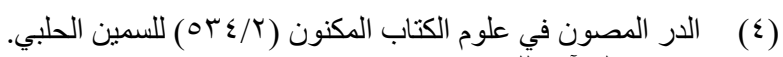

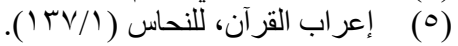

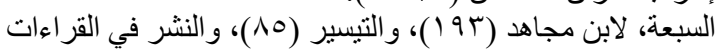

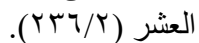

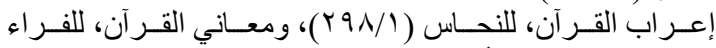

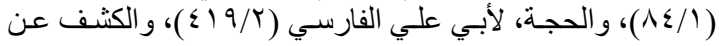

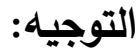

أما على قراءة أبان بن تغلب ومَنْ وافقهه بكسر الدال

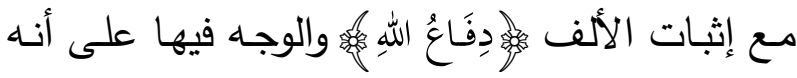
يجـوز أن يكـون مصسدراً لِفَعَلن، نحـو كَتَبَ كتابـاً،

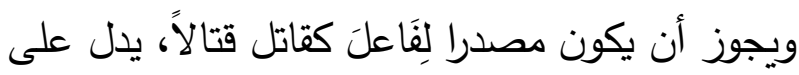

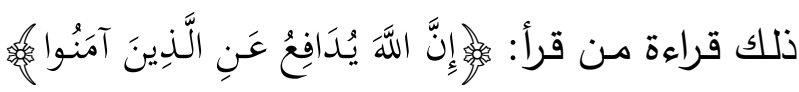

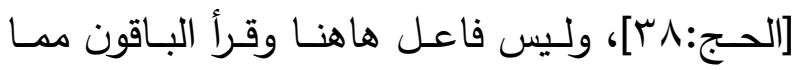

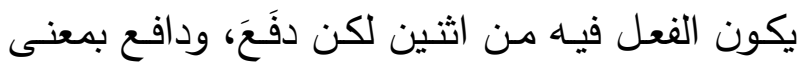

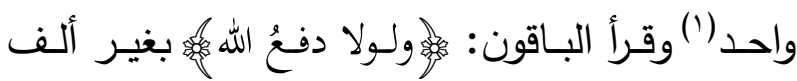

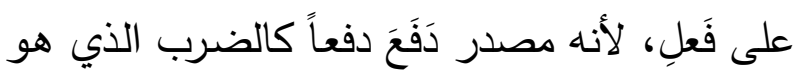

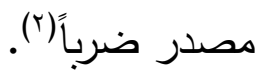

\section{أثرها في التفسير:}

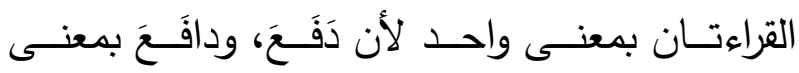

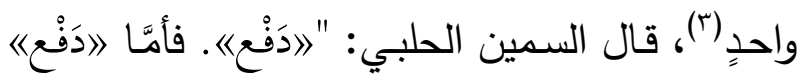

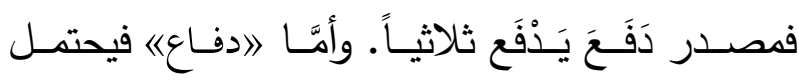
وجهين: أحدُهما: أن يكونَ مصدر دَفَعَ الثلاثي أيضاً

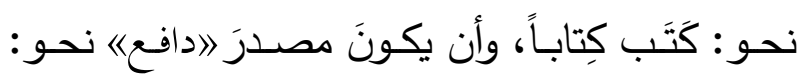
قاتل قِتالاً، قال أبو ذؤيب:

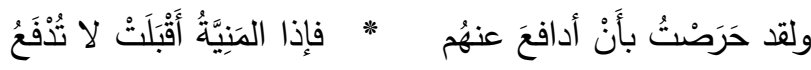
و (فاعَل) هنا بمعنى فَعَل المجرد فتتَّحد القراءتان في
انظر : المر اجع السابقة.

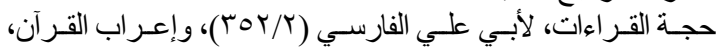

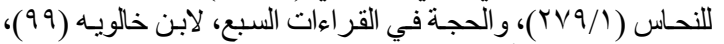

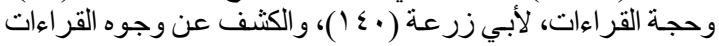

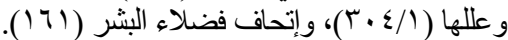

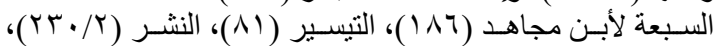

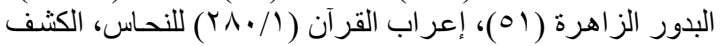

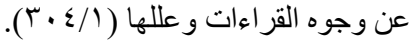


يمكن إدغام في سـاكن، فحركنا الثانيـة بالفتحة هربـا

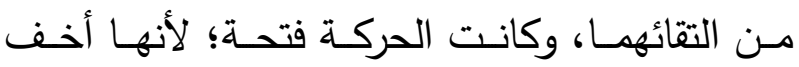
الحركات، وأن وما في حيزها في محل نصب أو جر بعد حذف حرف الجر، وهي لام العلة، والتقدير : لأن تضل، أو إرادة أن تضل ('). ثالثاً: سورة آل عمران:

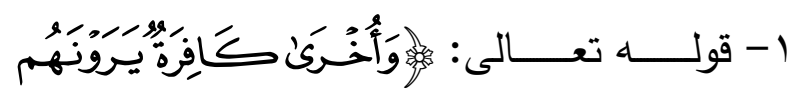

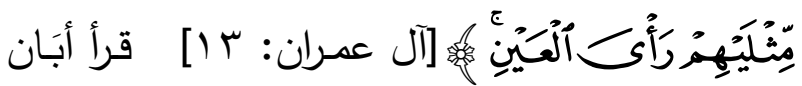

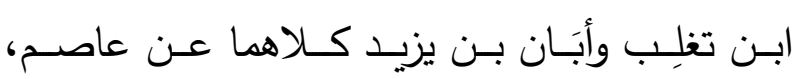
والفضل عن حفص عنـه بالتـاء(؟) وحكى أبان عن ئن

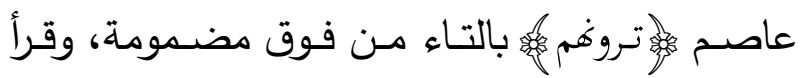
الباقون:

\section{التوجيه:}

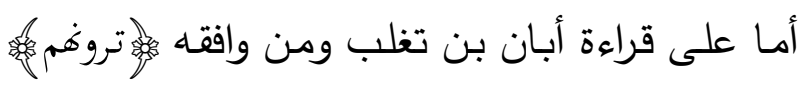
بالتاء، وذلك لأن مـا قبله خطاب، وهو قوله تعالى:

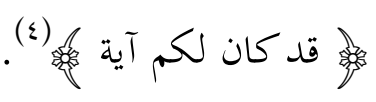

\section{أثرها في التفسير:}

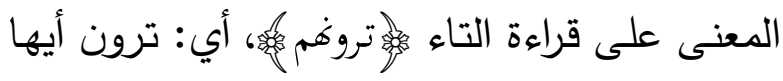
المسلمون المشركين مثلَي المسلمين والقياس مثليكم،

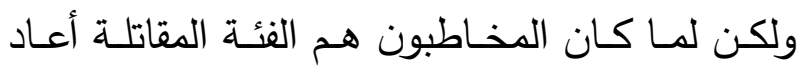

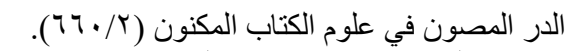

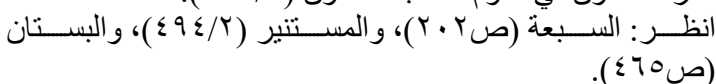

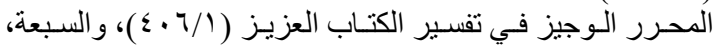

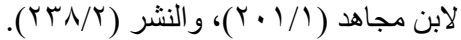

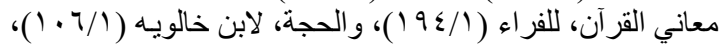

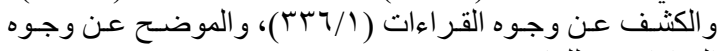

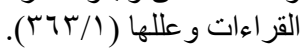

\section{أثرها في التفسير:}

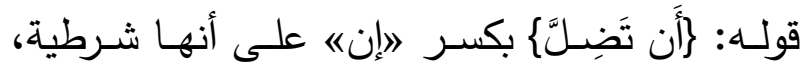
والباقون بفتحها، على أنها المصدرية الناصبة، فأما

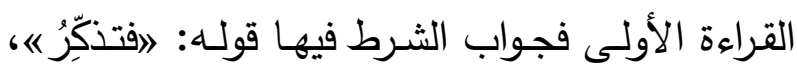
وذلك أن حمزة - رحمه الله - يقرأ: 》فَتَتَكِّرُ بتشديد الكاف ورفع الراء فصح أن تكون الفاء وما في حيزها جوابـا للشـرط، ورفع الفعل لأنه على إضـمار مبتدأ أي: فهـي تُذِكِرِ ، وعلى هـذه القـراءة فجملـة الشـرط والجزاء هل لها محل من الإعراب أم لا؟ فقال ابن عطية: "اإنَّ محلَّها الرفعُ صفةًَ لامرأتينه، وكان قد تقدم أن قوله: 》امِسَّنْ تَزْضَوْنه صففة لقوله: افرجلُ

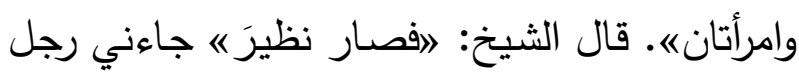
وامرأتان عقلاءُ حُبْلَيَان وفي جواز مثل هذا التركيب نظر ، بل الذي تقتضيه الأقيسة تقديم 》حُبْلَيَانه على 》عقلاء 《؛ وأما إذا قيل بأن 》ممَّنْ تَرْضَوْنه بدل من

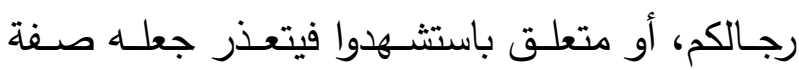
لامـرأتين للـزوم الفصـل بــين الصـفة والموصــوف بأجنبي، والظـاهر أن هذه الجملـة الثـرطية مستأنفة للإخبار بهذا الحكم، وهي جواب لسؤال مقدر ، كأن قائلا قال: ما بال امرأتين جعلتا بمنزلة رجل؟ فأجيب بهذه الجملة. وأمــا القـراءة الثانيـة فـهأَنْ فيهـا مصـدرية ناصـبة بعدها، والفتحة فيـه حركة إعراب، بخلافها في قراءة

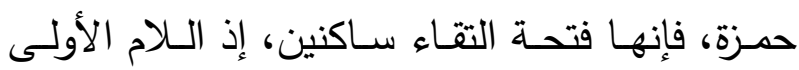
ساكنة للإدغام في الثانية، والثانية مسكنة للجزم، ولا 
والكفران"(7)، وقـال الطبري: "فأمــا "الرُّضـوان" بضـــ

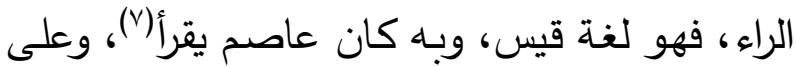

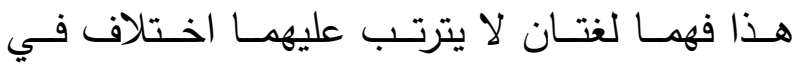

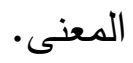

ץ- قولـه تعـالى:

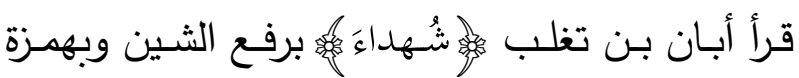

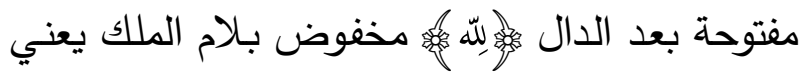

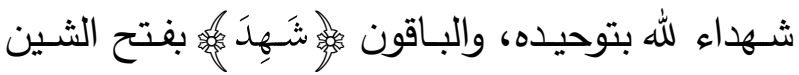
. (^)

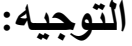

ذكر الزمخشري، أنـه قرىء: شهداء لله، برفع الهمزة

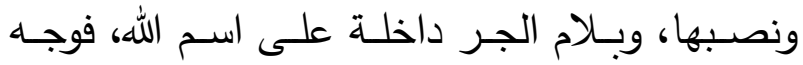

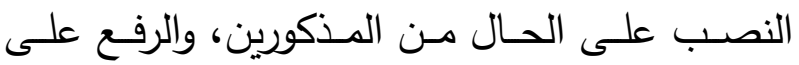
إضمارهم، ووجها رفع الملائكة على هاتين القراءتين عطفا على الضمير المستكن في شهاء، وجاز ذلك فئك لوقوع الفاصل بينهما"(9). وقال النحاس: "فأما قراءة أبي المهلب شُهَداءَ لِلَّهِ فهي

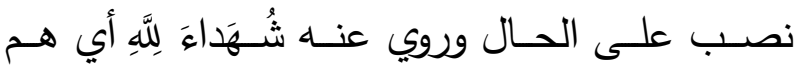
شهداء الله ويروى عنـه شهداء الله ويروى عنه شهداء

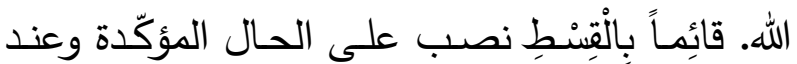

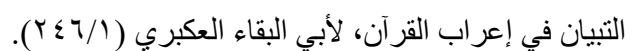

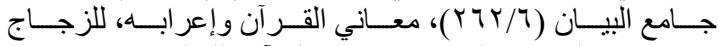

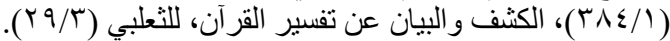

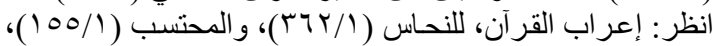

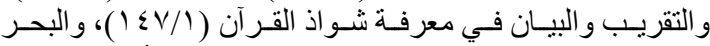

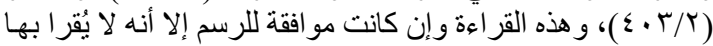

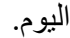

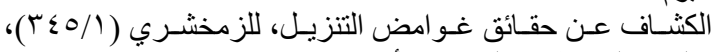

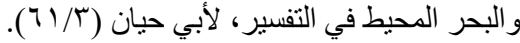

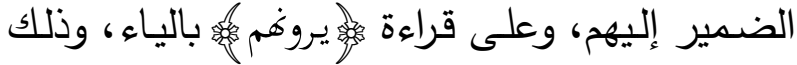

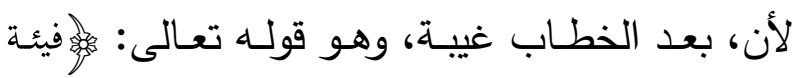

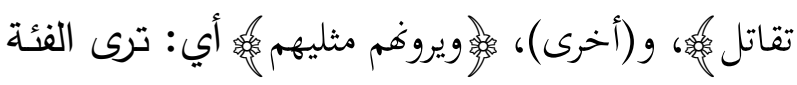
المقاتلة في سبيل الله الفئة الكافرة مثلي أنفسهم ('). ץ- قوله تعالى: قرأ عاصم إلا حفصاً، وأبان بن تغلب برفع الراء في جميع القرآن والباقون بكسر الراء (؟).

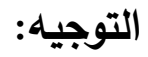

أما على قراءة أبان بن تغلب ومن وافقه بضم الواو وحجتهم في ذلك:

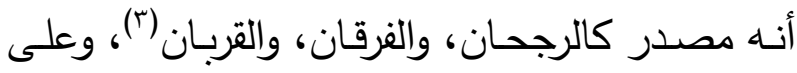

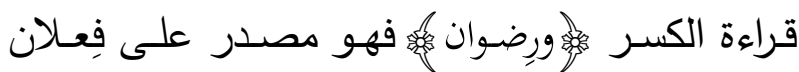
كالرئمان، والحرمان، وكلتاهما لغتان والكسر أكثر (؛). أثرها في التفسير:

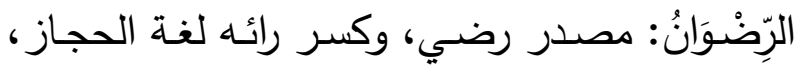
وضـمها لغــة تمـيم وبكر ، وقيس، وغيلان. وقيـل: الكسـر للاسـ، ومنـه: رِضْوَانٌ خـازن الجنـة، والضـم

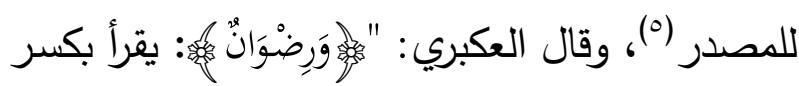
الراء وضـمها، وهمـا لغتـان، وهـو مصدر ، ونظير الكسـر الإتيـان والحرمــان، ونظيـر الضـم الثـكران

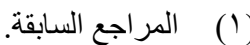

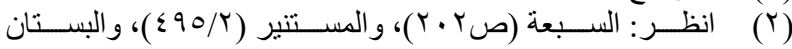

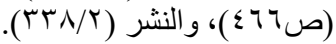

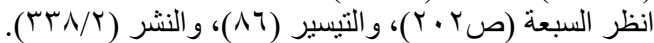

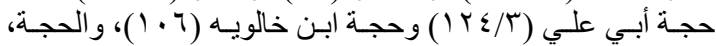

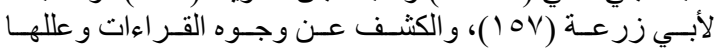

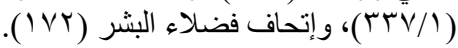

$$
\begin{aligned}
& \text { البحر المحيط في التفسير (ك/ ( 0). }
\end{aligned}
$$


[الروم:9 [ج] ووجها من قرأ بالنون قوله: كفروا فأعذبهم يُه [آل عمران:407]؛ فقوله:

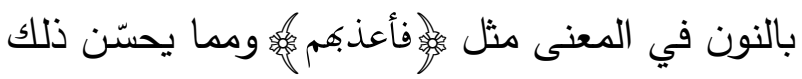
قوله: أثرها في التفسير:

قال النحاس: "والمعنى واحد على القراءتين أي:

فيوفيهم الله أجورهم"(7).

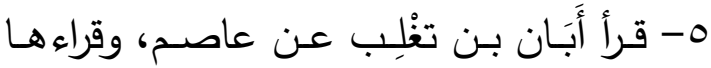

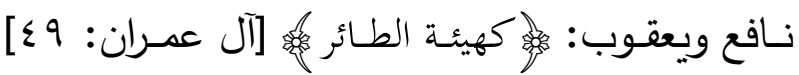
بألف وبالهمزة ومثله في [المائدة: . 1 1 ] والباقون بغير

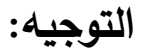

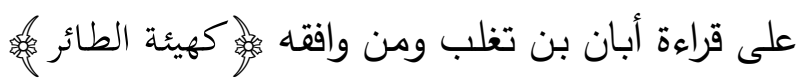
بـألف وبـالهمزة، لأن المـراد مـا أخلقـه يكـون طـائراً، فأفرد على معنى أن كل واحد من تلك الصور يكون لان الكراد طـائرا، كمـا قـال تعـالى: [النور :؟] أي كل واحد منهم، وعلى قراءة الباقون:

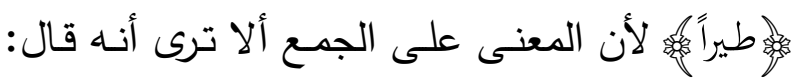

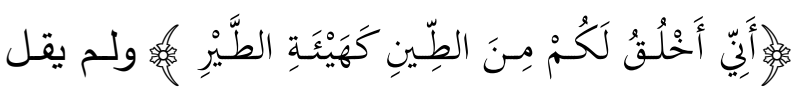

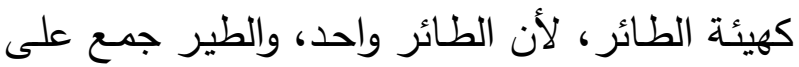

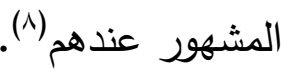

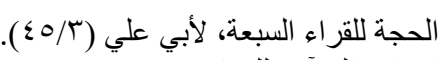

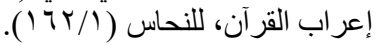

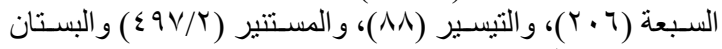

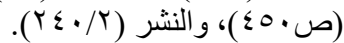

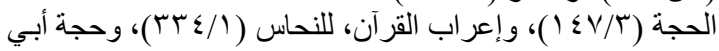

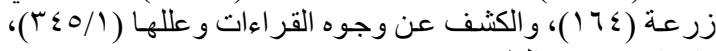

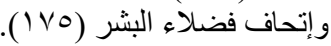

الكوفيين على القطع"( ) (1) أثرها في التفسير:

قـال أبـو عبيـدة معنسى وحقيقته أنسه علم وبين الله، لأن الثـاهد هـو العـالم

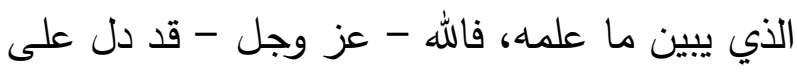

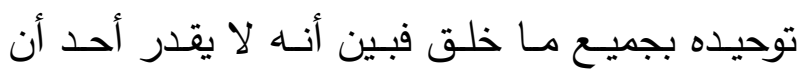

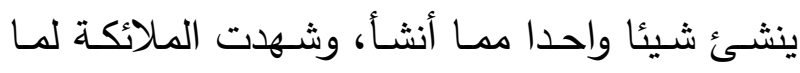
علمت من قدرته وشهد أولو العلم بما ثبت عندهم

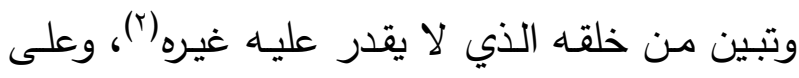

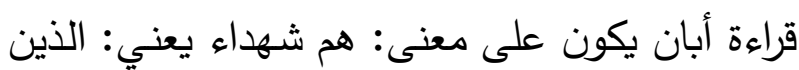
مر ذكرهم (r).

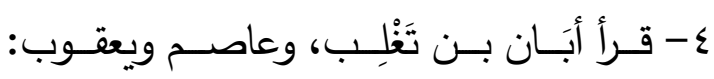

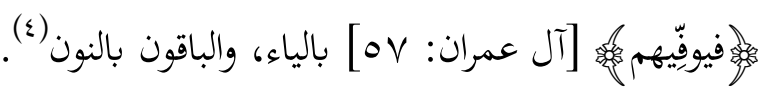

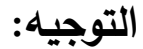

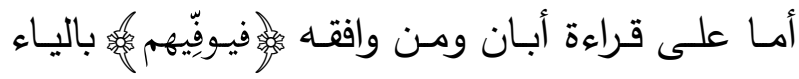
فلأنّ ذكر الله - سبحانه- قد تقدّم في قوله: ئر إذ قال الله يا عيسى إني متوفيـك ورافعـك إلي كُه آل عمـران:

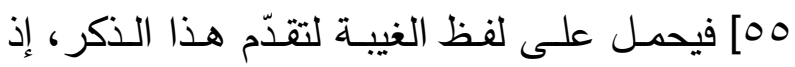
صـار في لفظ الخطـاب في قولـه: فأعذبهم وقولـه:

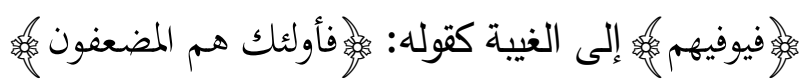

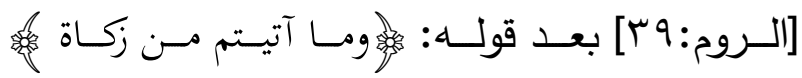

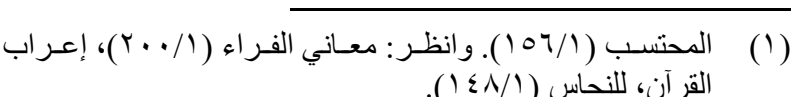

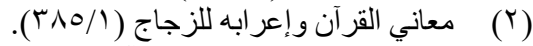

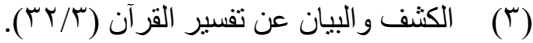

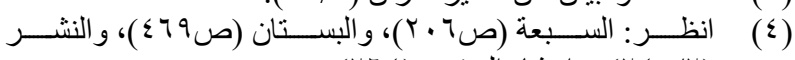

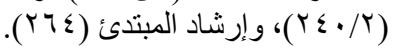


بفتح التاء وما أشبهه، ويؤيد المعنى الأول قراءة أبيّ

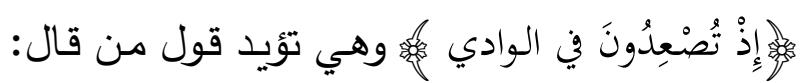

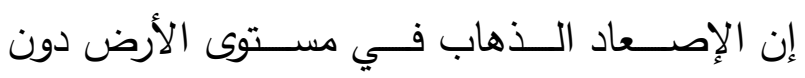

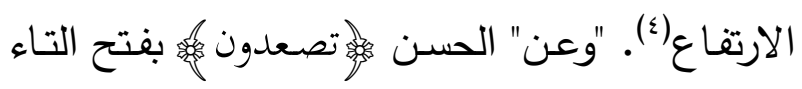
والعين من صعد في الجبل إذا رقى والجمهور بضم لإنمن

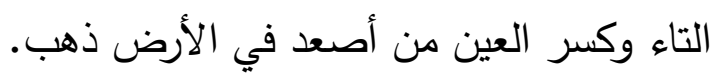
أثرها في التفسير:

يختلف المعنى في القراءتين: فـالمعنى على قراءة

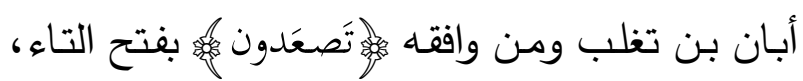
من الصعود إلى أعلى في جبل أو غيره، وعلى قراءة

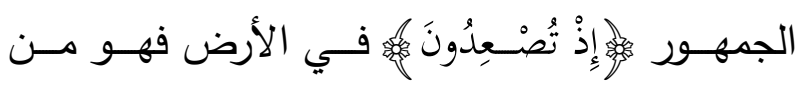

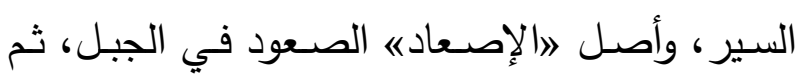
جعلوه في الدّرج، ثم جعلوه في الارتفاع في الأرض،

$$
\text { أصعد فيها: أي تباعد (०). }
$$

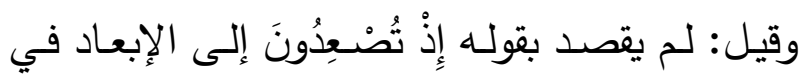

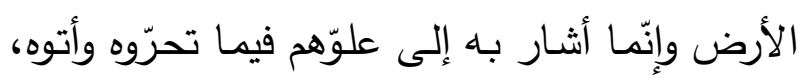

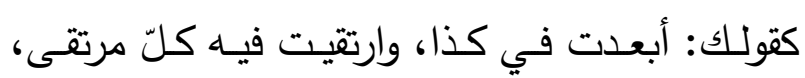

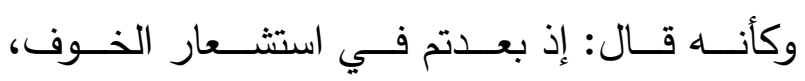

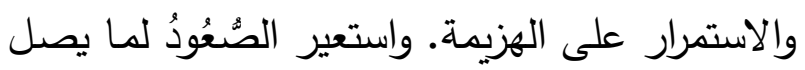

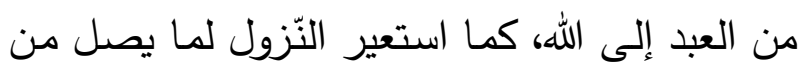

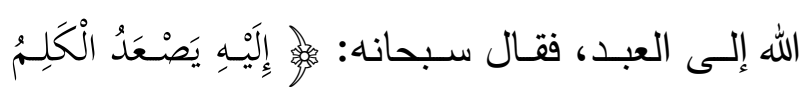

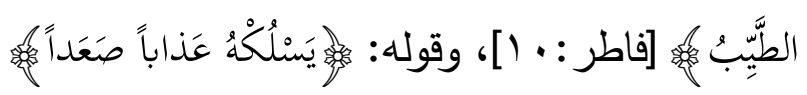

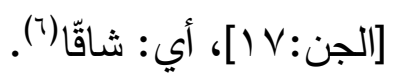

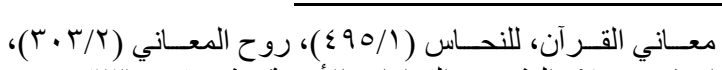

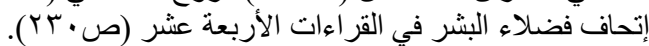

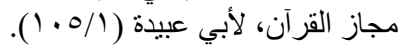

$$
\begin{aligned}
& \text { المفردات في غريب القرآن (ص: ع^ى ). }
\end{aligned}
$$

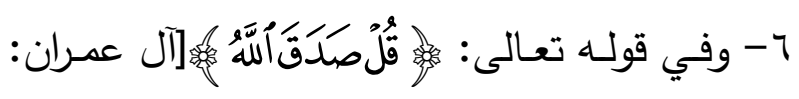
90 فِي الصَّادِ، و و

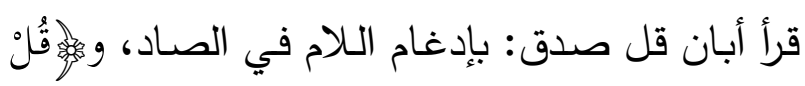

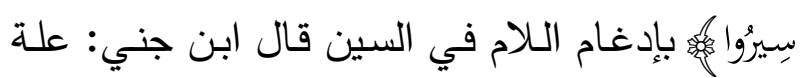
ذلك فثـو هذين الحرفين في الفم وانتثـار الصـوت باتدي المثبـت عنهمـا، فقاربتـا بــلكلك مخـرج الــلام، فجـاز إدغامها فيهما انتهى. وهو راجع لمعنى كلام سيبويه، قال سيبويه: والإدغام يعني إدغام الـلام مـع الطـاء والصاد وأخواتهما جائز ، وليس ككثرته مع الراء، لأن هذه الحروف تراخين عنهـا وهي من الثنايـا. قـال:

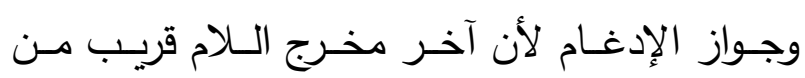
مخرجها انتهى كلامه (ז).

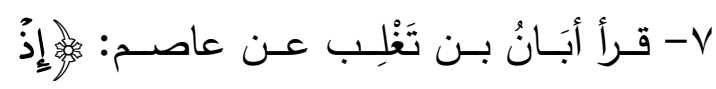

تُصــعِدُوبْ والعين وقرأ الجمهور

العين (r).

\section{التوجيه:}

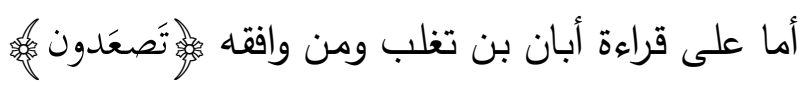

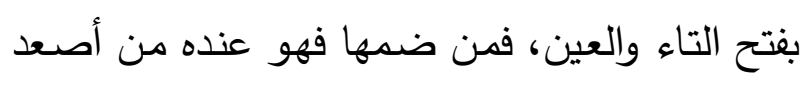

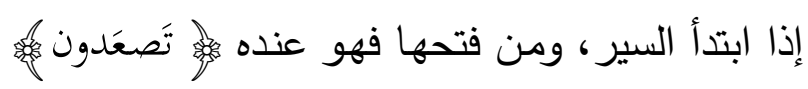

$$
\begin{aligned}
& \text { ( ) ( البحر المحيط (T/VT/T). } \\
& \text { المرجع السابث. }
\end{aligned}
$$

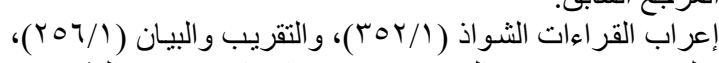

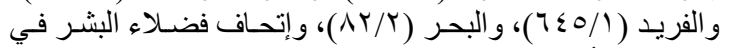




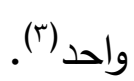

قال ابن الجزري: وقرح القرح ضم صحبة(ء). أثرها في التفسير: هـا لغتـان - كالدف والـدف، والضـعف، والضـعف، ومعنــاه الجـرح، وقيـل المفتـوح الجـرح والمضــموم ألمه (0).

\section{الخاتمة}

الحمـد الله الـذي وفقتـي لإتمـام هـذا البحـث، والـذي تناولت فيـه، "قراءة أبـان بـن تغلب موافقـة ومخالفــة

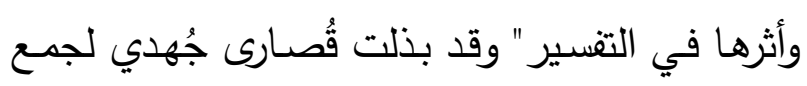
قراءة أبـان بن تغلب بشكل كامل في سور الفاتحـة

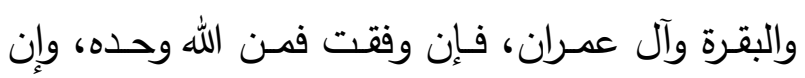
كانت الأخرى فحسبي أني بشر أصيب وأخطئ، وقد توصـلت مـن خـلال بحثي هذا إلىى بعض النتائج والتوصيات. أولا: النتائج:

1- قراءة أبان بن تغلب من القراءات الثاذة. r- قراءة أبان بن تغلب موافقة لقراءة الكوفيين في الأصول.

ب- كـان لكتب التفاسـير مـع كتـب القـراءات

واللغة الحظ الوافر في إيراد قراءة أبان بن تغلب.

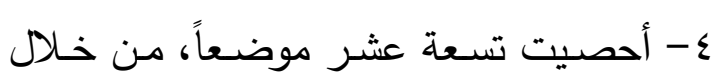
سورة الفاتحة، والبقرة، وآل عمران، قد نصَّ فيها أهل

إعراب القرآن، للنحاس (1/1/1) وحجـة القراءات، لابن زنجلة

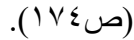

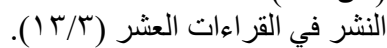

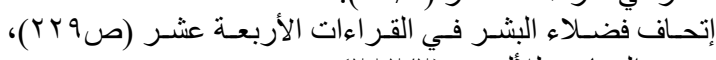

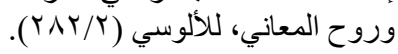

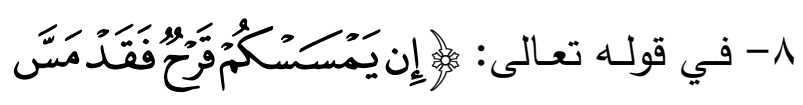

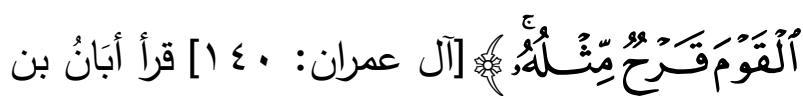

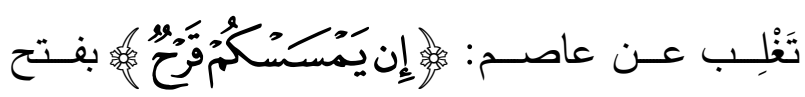

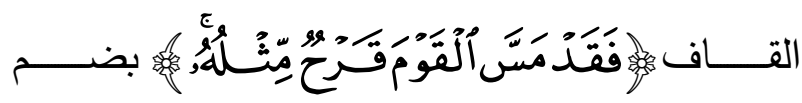
القاف، والباقون بفتح القاف فيهما('). التوجيه:

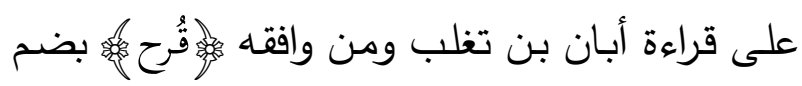
القاف، وقرأ الباقون بفتح القاف، وهما مصدران لقرح والقَرح بفتح القـاف: الأثر : مـن الجراحـة مـن شـيء يصسيبه مـن خـارج، والقُرح بضـم القـاف: أثرهـا مـن داخل كالبشرة ونحوها، وقد يقال: القرح بفتح القاف: للجراحة، وبالضم للألم (r). قَالَ الْفراء كَأَنْ الْقرح بِالضَّمِّ ألم الْجِرَاحَات وَكَأن الْقرح

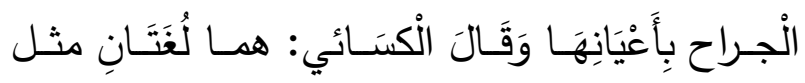

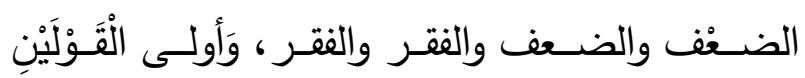

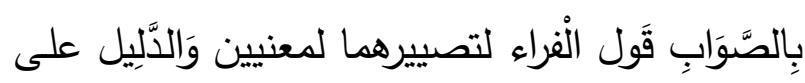

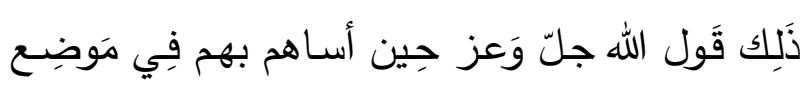

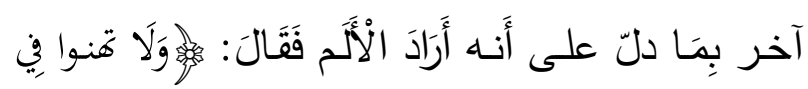

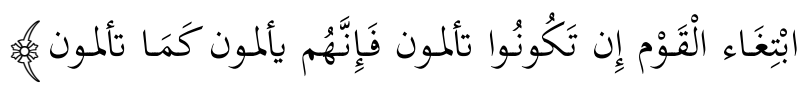

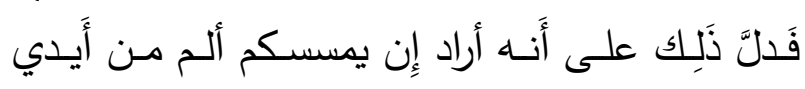
الْقَوْم فَاْن بهم من ذَلِكِ مثل مَا بكم وقال الأخفش هما

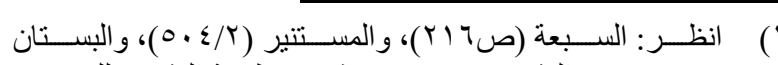

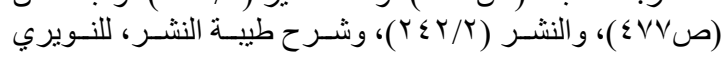

$$
\begin{aligned}
& \text { ( }(Y \leq T / Y)
\end{aligned}
$$

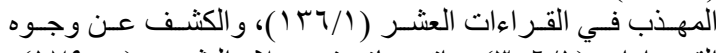

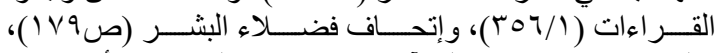

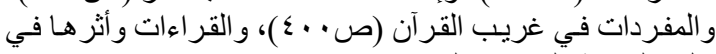


إرشاد البصير إلى سنية التكبير عن البشير النذير

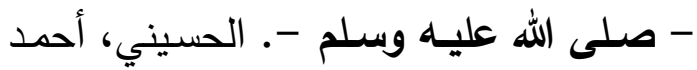
الزعبي. طا، د.م: دار الإمام مسلم، د.ت. إرواء الغليـل في تخـريج أحاديـث منسار السببيل. الألباني، محمد ناصر الدين. طَ، بيروت:

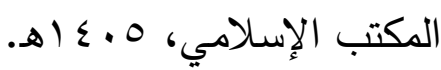
الإصابة في تمييز الصحابة. ابن حجر العسقلاني، أبو الفضل أحمد بن علي بن محمد بن أحمد.

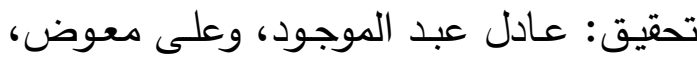
طا، بيروت: دار الكتب العلمية، 10 اء اهـ. أضواء البيان في إيضاح القرآن بالقرآن. الشنقيطي، محمد الأمين بن محمد المختار بن عبد القادر الجكني الثنقيطي. د.ط، بيروت: دار الفكر

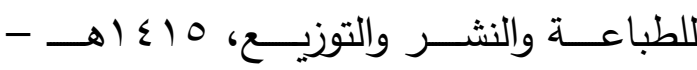
.01990

الإقناع في القراءات السبع. ابن الباذش، أحمد بن علي بن أحدد بن خلف الأنصاري. تحقيق: أحمد فريد المزيدي، طا، بيروت: دار الكتب الانب

العلمية، 919 ( أهـ.

إمسلاء مـا مـن بـه الـرحمن. العكبري، عبد الله بن الحسـين. طا، بيـروت: دار الكتـب العلميـة،

$$
\text { . } 11499
$$

المحيط في التفسير . أبو حيان، محمد بن يوسف بن علي بن يوسف بن حيان أثير

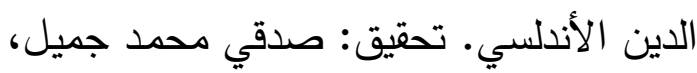
د.ط، بيروت: دار الفكر، . بـ الهـ.
العلم من القراء وغيرهم على قراءة أبان بن تغلب. ثانيا: التوصيات: 1- حث الباحثين وتحفيزهم، على البحث الجاد والعمل الدؤوب في جمع قراءة أعلام القراءات الثاذة،

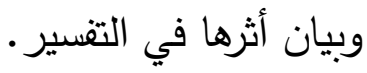
r- العمل على جمع قراءة أبان بن تغلب في العيد مصدر واحد حتى يمكن الإفادة منها. فهرس المصادر والمراجع الادان الإبانة عن معاني القراءات. مكي بن أبي طالب،

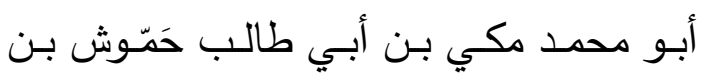
محمد بن مختار القيسي القيرواني. تحقيق: د. د. عبد الفتاح إسماعيل شلبي، د.ط، مصر : دار نهضة مصر للطبع والنشر ، د.ت. إتحاف فضـلاء البشر في القراءات الأربعة عشر. البنا، أحمد بن محمد بن أحمد بن عبد الغني الغني الدمياطيّ، شهاب الدين. حققه وقدم لـه: د. شعبان محمد إسماعيل، طا، بيروت: عالم لإله

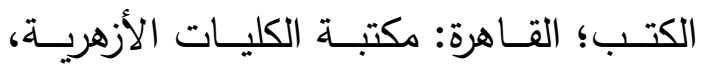
هـ $\{. \gamma$ الإتقـان في علوم القرآن. السيوطي، جلال الدين عبد الرحمن بن أبي بكر ـ طجا، بيروت: دار الكيار

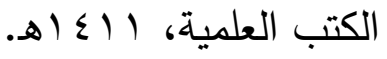
الإتقان في علوم القرآن. السيوطي، جلال الدين عبد الرحمن بن أبي بكر . تحقيق: محمد أبو الكي

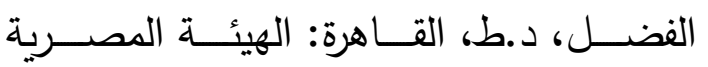

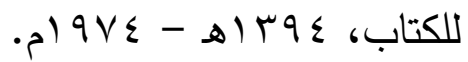


طاهر بن عبد المنعم. تحقيق: أيمن رشدي

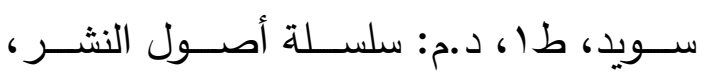
.ه $\leqslant 1 Y$

تفسير ابـن عطيـة = المحرر الـوجيز في تفسير

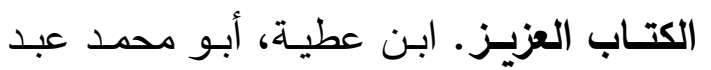
الحق بـن غالب بن عبد الرحمن الأندلسي. طا، بيروت: دار الكتب العلمية، بr أهـ. تفسير أبي السعود = إرشاد العقل السليم إلى مزايا

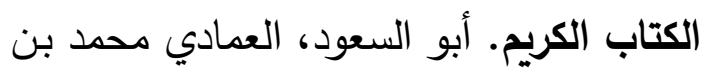
محمد بن مصطفى. د.ط، بيروت: دار إحياء

$$
\text { التراث العربي، د.ت. }
$$

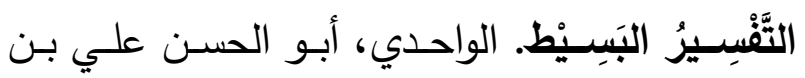

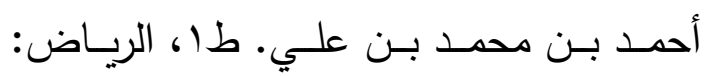

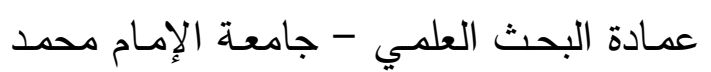

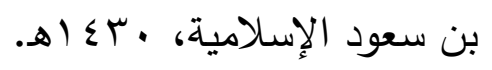

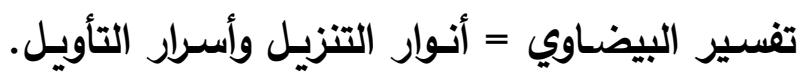
البيضاوي، ناصر الدين أبو سعيد عبد الله بن

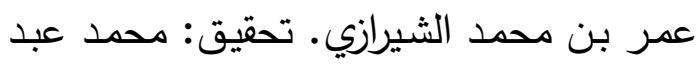
الرحمن المرعشلي، طا ، بيروت: دار إحيـاء

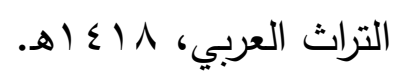

تفسير الثعلبـي = الكشـف والبيـان عـن تفسـير القرآن. الثعلبي، أحمد بن محمد بن إبراهيم.

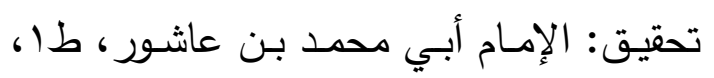

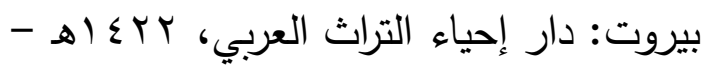

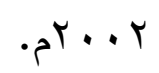
تفسيرير الثعلبـي = الكثـف والبيـان عـن تفسـير
البداية والنهاية. ابن كثير، أبو الفذاء إسماعيل بن

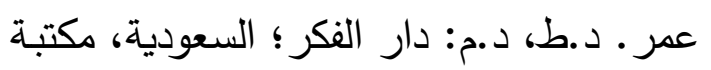

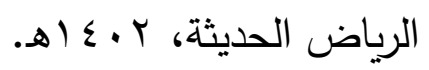
البــدور الزاهـرة فـي القـراءات العثــر المتــواترة. القاضي، عبد الفتاح بن عبد الغني بن محمد. طا ، القاهرة: شركة مصطفى البابي الحلبي، (ITVO البــدور الزاهـرة فــي القـراءات العثــر المتــواترة. القاضي، عبد الفتاح بن عبد الغني بن محمد.

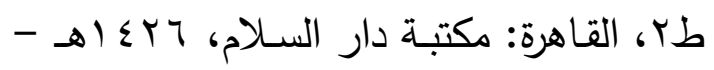
. البرهان في علوم القرآن. الزركثي، بدر الدين محمد

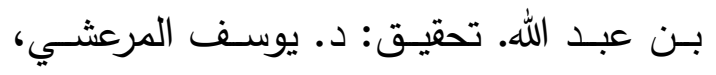

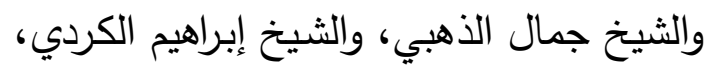
طا، بيروت: دار المعرفة، • إئ أهـ.

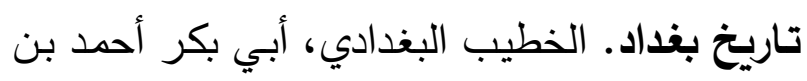

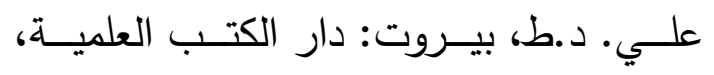

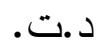
تعبيـر التيسـير في قـراءات الأئمسـة العشـرة. ابن الجزري، محمد بن محمد. تحقيق: الثيخ عبد

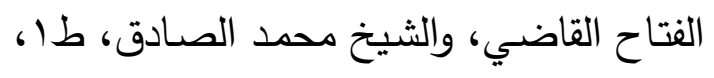
حلب: دار الوعي، بو ب أهـ

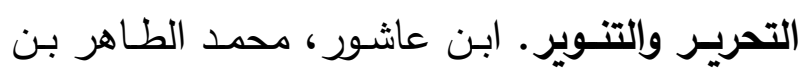
محمد بن محمد. د.ط، تونس: الدار التونسية

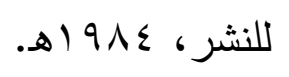

التذكرة في القراءات الثمان. ابن غلبون، أبو الحسن 
عثمـان بـن سـعيد. طـا، الإمـارات: جامعـة

$$
\text { الشارقة، }
$$

جامع البيـان في تأويـل القرآن. الطبري، أبو جعفر

محمد بن جريـر • تحقق: أحمد محمد شـاكر،

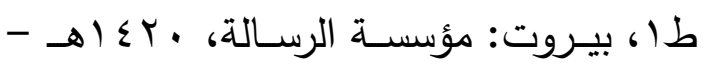

$$
\text { . }
$$

الجامع لأحكام القرآن = تفسير القرطبي. القرطبي،

أبو عبد الله محمد بن أحمد بن أبو بكر بن

فرح الأنصاري الخزرجي شمس الدين. تحقيق:

أحمد البردوني، وإبراهيم أطفيش، طن، القاهرة:

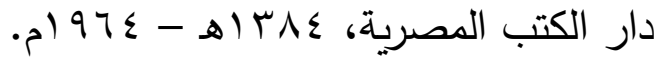

الجواهر الحسـان في تفسير القـرآن. الثعالبي، أبو

زيد عبد الرحمن بن محمد بن مخلوف. طا اك

بيروت: دار إحياء التراث العربي، 1 اءـ اهـ.

حجة القراءات. ابن زنجلة، عبد الرحمن بن محمد،

أبـو زرعـة. محقـق الكتـاب ومعلـق حواشـيه:

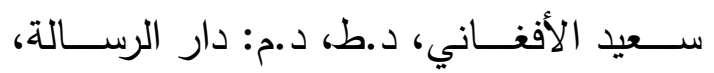

د.ت.

الحجة في القراءات السبع. ابن خالويه، أبو عبد الله الحسين بن أحمد. طء، بيروت: دار الشروق،

$$
\text { . } 1 \text { ( ) } 1
$$

الحجة للقراء السبعة. أبو علي الفارسي، الحسن بن أحمد بن عبد الغفار • طץ، دمشق - بيروت:

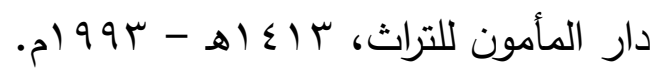

روح المعـاني فـي تفسير القـرآن العظيم والسـبع المثـاني. الألوسـي، أبـو الثـاء شـهاب الدين
القرآن. الثعلبي، أحمد بن محمد بن إبراهيم. طا، جدة - المملكـة العربيـة السـودية: دار

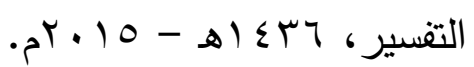
تفسير الرازي = مفاتيح الغيب أو التفسير الكبير. الرازي، فخر الدين أبو عبد الله محمد بن عمر بـن الحسـن. طّ، بيـروت: دار إحيـاء التراث

$$
\text { العربي، · · أهـ }
$$

تفسير الزمخشري = الكشاف عن حقائق غوامض التتزيـلـ الزمخشـري، أبـو القاسـم محمـود بـن عمرو بـن أحمـد. طس، بيـروت: دار الكتاب

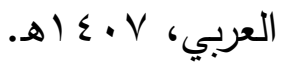

تفسير القرآن العظيم. ابن كثير ، أبو الفداء إسماعيل بـن عمـر • طـ الريـاض: دار طيبـة للنشـر

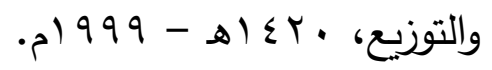
تفسير المـاوردي = النكـت والعيون. المـاوردي أبو الحسـن علي بـن محمـد بـن محمـد. تحقيـق: السيد ابن عبد المقصود بن عبد الرحيم، د.ط، بيروت: دار الكتب العلمية، د.ت. التيسـير فـي القـراءات السـبع. الداني، أبـو عمرو عثمـان بـن سـعيد. طا ها، حائـل - السـعودية:

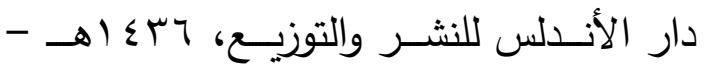
$\cdot 5 \cdot 10$ جـامع البيــان فـي القـراءات الســبع المشــهورة (مخطـوط). الـداني، أبـو عمـرو عثــان بـن سعيد. مصور عن دار الكتب المصرية. جامع البيان في القراءات السبع. الداني، أبو عمرو 
صحيح ابن خزيمـة. ابن خزيمة، أبو بكر محمد بن

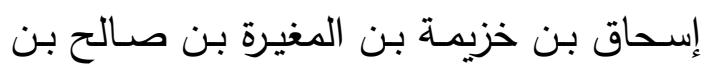

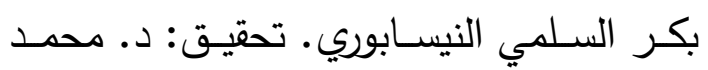

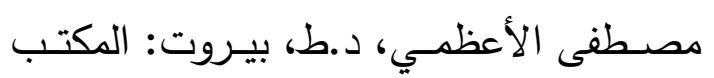

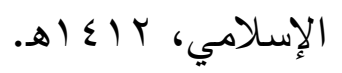
صحيح البخاري. البخاري، محمد بن إسماعيل أبو

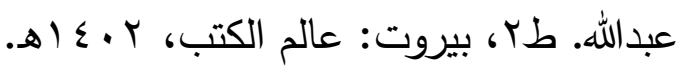
غاية النهاية في طبقات القراء. ابن الجزري، شمس الدين أبي الخير محمد بن محمد بن محمد. د.ط، القاهرة: مكتبة الخانجي، د.ت. فتح القدير . الشوكاني، محمد بن علي بن محمد بن عبد الله. طا، دمشق: دار ابن كثير؛ بيروت:

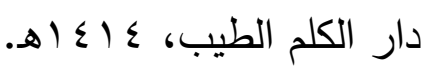
فريـدة الـدهر في تأصسيل وجمـع القـراءات. سـالم، محمد إبراهيم محمد. طا ، القاهرة: دار البيان

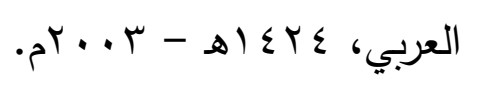

القــاموس المدـيط. الفيروزآبـادي، مجـد الـدين أبـو طاهر محمد بن يعقوب. توثيق: يوسف الثيخ البقاعي، بيروت: دار الفكر، 0 أـ أهـ

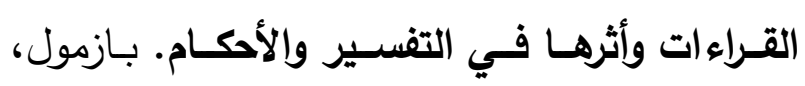

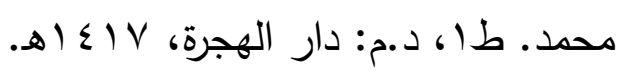
كشف الظنون عن أسـامي الكتب والفنون. حاجي خليفــة، مصــفى بـن عبــــ الله كاتـب جلبـي القسطنطيني. طس، بيروت: دار إحياء التراث

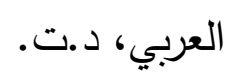

الكثف عن وجوه القراءات السبع وعللها وحججها.
محمود. د.ط، دمشق: دار الفكر، و آهـ زاد المسير في علـم التفسير • ابن الجوزي، جمال الدين أبو الفرج عبد الرحمن بن علي. تحقيق: عبد الرزاق المهدي، طا، بيروت: دار الكتاب العربي6، بr أهـ السبعة في القراءات. ابن مجاهد، أبو بكر أحمد بن موسى بن العباس التميمي. طب، مصر : دار

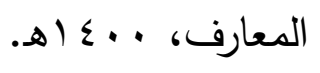
سير أعـلام النبلاء. الذهبي، شمس الدين أبو عبد ، أداد الله محمـد بـن أحمـد بـن عثمـان بـن قَايْمـاز • طا (ا، د.م: مؤسسة الرسالة، د.ت. شرح طيبة النشر في القراءات. ابن الجزري، شمس فوسله الدين أبو الخير • ضبطه وعلق عليه: الشيخ أنس مهرة، طب، بيروت: دار الكتب العلميـة، . شـرح طيبـة النثـر للنُّوَيْري. محمد بـن محمد بـن أهن محمد، أبو القاسم، محب الدين. طاه بيروت:

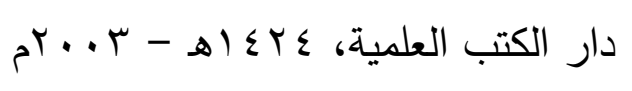
شواذ القراءات. الكرماني، أبو عبدالله محمد بن أبي نصــر • تحقيـق: د. شــران العجيلـي، د.ط،

$$
\text { بيروت: مؤسسة البلاغ، د.ت. }
$$
الشــواذ فـي وجـوه القــراءات. القـاري، دُـلا علـي. (مخطوط) الصـحاح تــاج اللغـة وصـحاح العربيـة. الجوهري، إسماعيل بن حماد. تحقيق: أحمد عبدالغفور

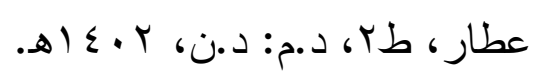


المحتسب في تبيين وجوه شواذ القراءات والإيضساح عنها. ابن جني، أبو الفتح عثمان الموصلي.

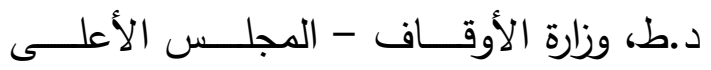

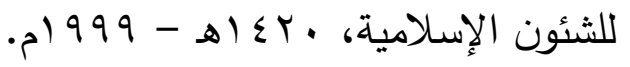

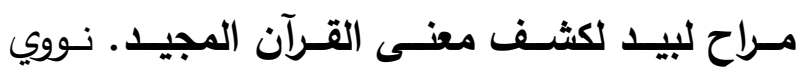

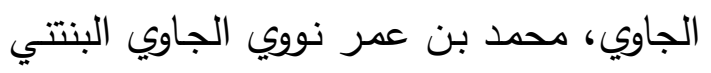

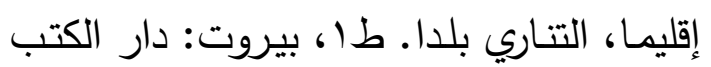

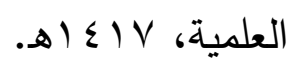

المرشد الوجيز إلى علوم تتعلق بالكتاب العزيز ـ أبو اهو

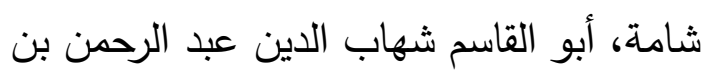
إسماعيل بن إبراهيم المقدسي. تحقيق: طيار

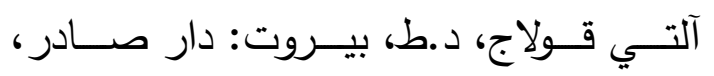

$$
\text { . } 9 \text { 190 - ه }
$$

المصـاحف. ابن أبي داود، عبد الله بن سليمان بن

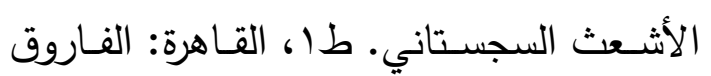

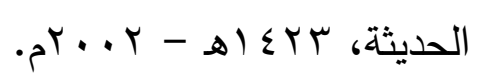

معـاني القـراءات للأزهـري. الأزهري، أبـو منصـور

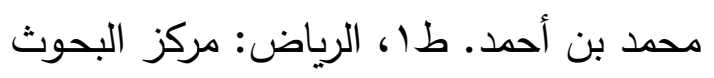

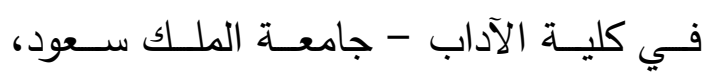

$$
\text { . } 991 \text { - اله }
$$

معاني القرآن للفراء. الفراء، يحيى بن زياد بن عبد

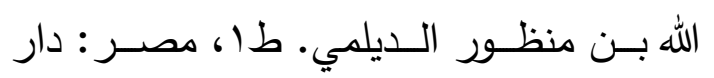
المصرية للتأليف والترجمة، د.ت. معاني القرآن وإعرابـه للزجاج. الزجاج، أبو إسحاق ولترجة د.

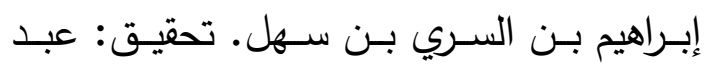

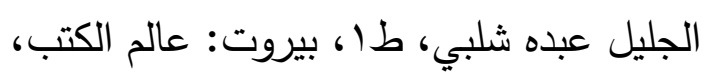

القيسي، أبـو محمــ مكي بـن أبـي طالب.

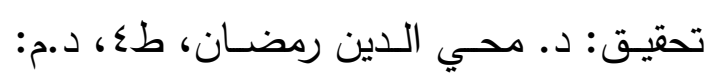
د.ن، V • أهـ

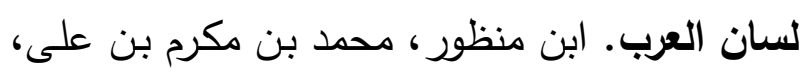

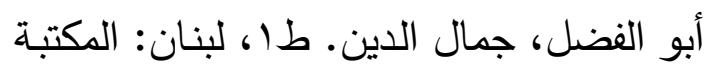

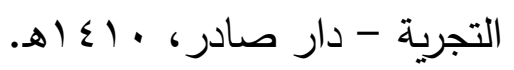

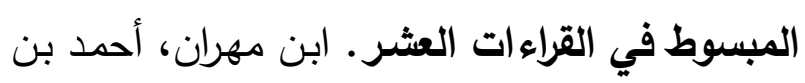

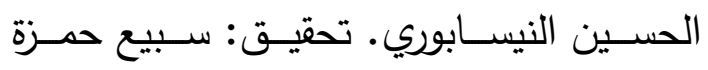
حـاكمي، طب، جــدة: دار القبلــة؛ ســـوريا:

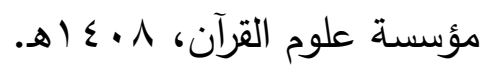

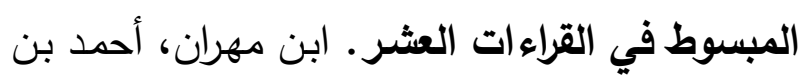

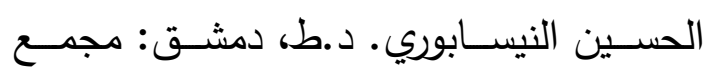

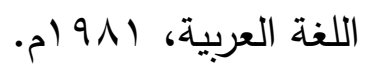

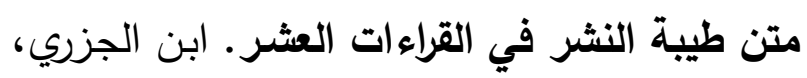

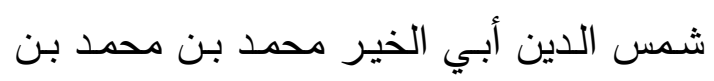

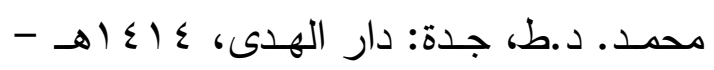
$.0199 \varepsilon$ مجـاز القرآن. أبو عبيدة، معدر بن المثنى التيمى

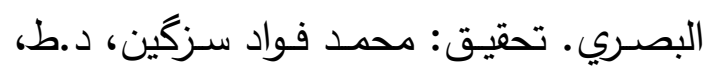

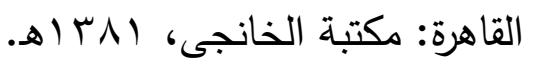
مجموع الفتاوى. ابن تيمية، تقي الدين أبو العباس الهان

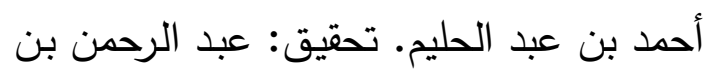

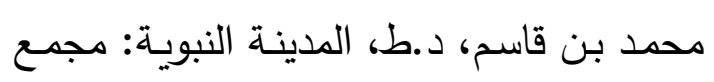

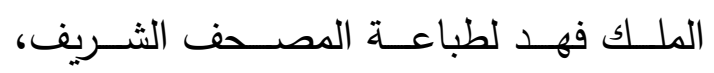
. $990-81 \leq 17$ مجموع فتاوى شيخ الإسلام ابن تيمية 
النشـر في القـراءات العثـر • ابـن الجزري، شـس الدين أبـو الخير محمد بـن محمد. تحقيـق: علـي محمـد الضــباع، د.ط، د.م: المطبعـة التجارية الكبرى، د.ت. الـوجيز في تفسير الكتـاب العزيـز ـ الواحدي، أبـو الحسـن علي بـن أحمـد بـن محمد بـن علي النيسـابوري. تحقيق: صفوان عدنان داوودي، طا، دمشــق، بيــروت: دار القلـــ، الـــدار الشامية، 0 إك أهـ. الوسيطيط في تفسير القـرآن المجيــ. الواحدي، أبو الحسـن علي بـن أحمـد بـن محمد بـن علي النيسابوري. طا، بيروت: دار الكتب العلمية، . 2) $99 \leq-8 \leq 10$ وفيـات الأعيـان وإنبـاء أبنـاء الزمـان. ابن خَلِّكَان، أحمد بـن محمد. تحقيق: د. إحسـان عبـاس،

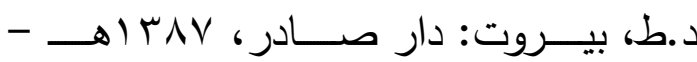
•p) 971

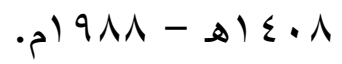

معرفـة القـراء الكبــار علـى الطبقــات والأعصــار. الـذهبي، شـمس الـدين محمـد بـن أحمـد بـن عثمان بن قايماز • تحقيق وتعليق: بشار عواد معروف، وشـيب الأرناؤوط، وصـالح مهدي عبــاس، طا، بيــروت: مؤسســـة الرســـالة،

$$
\text { - P) } 9 \wedge \leqslant-\infty 1 \leqslant \cdot \varepsilon
$$

مقـاييس اللفـة. ابـن فـارس، أحمـد بـن فـارس بـن زكريـاء القزويني الرازي. تحقيق: عبد السـلام

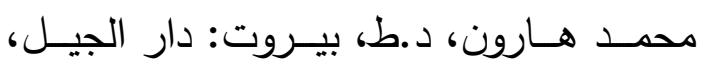
د.ت. منجــ المقـرئين ومرشـــ الطـالبين. ابـن الجزري، شمس الدين أبو الخير محمد بن محمد. طا كا، مكة المكرمة: دار عالم الفوائد، 9 (1 أهـ. الموضح في وجوه القراءات وعللها. ابن أبي مريم، نصر بن علي بن محمد أبي عبدالله الشيرازي. تحقيـق: د. عمـر حمـدان الكبيسـي، بيـروت:

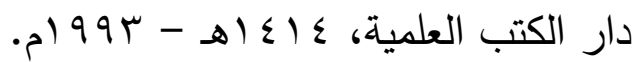




\title{
Reciting Aban Bin Thalb with approval and disagreement and its effect on interpretation
}

\author{
Dr. Mohammad Ahmad Mohammad binmuaed Alhawash \\ Associate Professor in College of Sharia and \\ Principles of Islamic Religion
}

\begin{abstract}
It includes an introduction' two topics and a conclusion' I spoke in the introductionOn the definition of the science of readings and its importancer then I explained in the first topic the definition of anomalous readings language and idiomIt was created and written down' the most important works in it، the readers 'flags in it، and the ruling on invoking them in rulings، interpretation'And she added with a brief definition of Aban bin Thalb، in which I mentioned his birth، his upbringing، his works، his elders، and his disciples.Then it was concluded with the second and final research' in which the recited recitations were collected on the authority of Aban Bin Thalb in Surat Al-Fatihah' Al-Baqarah، and the Imran familyIndicating what the public agreed with or disagreed with and the effect of that on the interpretation، Then the conclusion includes: the most important results and recommendations، the proven sources and references، then the indexes.
\end{abstract}

key words: Narration - Abban- Bin Taghlib - Readings- Holly Qur'an. 